\title{
A Review on the Medicinal and Pharmacological Properties of Traditional Ethnomedicinal Plant Sonapatha, Oroxylum indicum
}

\author{
Ganesh Chandra Jagetia ${ }^{1,2}$ \\ 1 Department of Zoology, Mizoram University, Aizawl 796004, India; gc.jagetia@gmail.com \\ 210 Maharana Pratap Colony, Sector 13, Hiran Magri, Udaipur 313002, India
}

check for

updates

Citation: Jagetia, G.C. A Review on the Medicinal and Pharmacological Properties of Traditional

Ethnomedicinal Plant Sonapatha, Oroxylum indicum. Sinusitis 2021, 5 , 71-89. https://doi.org/10.3390/ sinusitis5010009

Received: 18 November 2020

Accepted: 20 May 2021

Published: 25 May 2021

Publisher's Note: MDPI stays neutral with regard to jurisdictional claims in published maps and institutional affiliations.

Copyright: (C) 2021 by the author. Licensee MDPI, Basel, Switzerland. This article is an open access article distributed under the terms and conditions of the Creative Commons Attribution (CC BY) license (https:// creativecommons.org/licenses/by/ $4.0 /)$.

\begin{abstract}
Oroxylum indicum, Sonapatha is traditionally used to treat asthma, biliousness, bronchitis, diarrhea, dysentery, fevers, vomiting, inflammation, leukoderma, skin diseases, rheumatoid arthritis, wound injury, and deworm intestine. This review has been written by collecting the relevant information from published material on various ethnomedicinal and pharmacological aspects of Sonapatha by making an internet, PubMed, SciFinder, Science direct, and Google Scholar search. Various experimental studies have shown that Sonapatha scavenges different free radicals and possesses alkaloids, flavonoids, cardio glycosides, tannins, sterols, phenols, saponins, and other phytochemicals. Numerous active principles including oroxylin A, chrysin, scutellarin, baicalein, and many more have been isolated from the different parts of Sonapatha. Sonapatha acts against microbial infection, cancer, hepatic, gastrointestinal, cardiac, and diabetic disorders. It is useful in the treatment of obesity and wound healing in in vitro and in vivo preclinical models. Sonapatha elevates glutathione, glutathione-s-transferase, glutathione peroxidase, catalase, and superoxide dismutase levels and reduces aspartate transaminase alanine aminotransaminase, alkaline phosphatase, lactate dehydrogenase, and lipid peroxidation levels in various tissues. Sonapatha activates the expression of p53, pRb, Fas, FasL, IL-12, and caspases and inhibited nuclear factor kappa (NF- $\mathrm{B}$ ), cyclooxygenase (COX-2), tumor necrosis factor (TNF $\alpha$ ), interleukin (IL6), P38 activated mitogen-activated protein kinases (MAPK), fatty acid synthetase (FAS), sterol regulatory element-binding proteins $1 \mathrm{c}$ (SREBP-1c), proliferator-activated receptor $\gamma 2$ (PPAR $\gamma 2)$, glucose transporter (GLUT4), leptin, and HPV18 oncoproteins E6 and E7 at the molecular level, which may be responsible for its medicinal properties. The phytoconstituents of Sonapatha including oroxylin A, chrysin, and baicalein inhibit the replication of SARS-CoV-2 (COVID-19) in in vitro and in vivo experimental models, indicating its potential to contain COVID-19 infection in humans. The experimental studies in various preclinical models validate the use of Sonapatha in ethnomedicine and Ayurveda.
\end{abstract}

Keywords: Oroxylum indicum; ethnomedicine; antioxidants; NF-кB; COX-2; p53

\section{Introduction}

Oroxylum indicum belongs to the family Bignoniaceae and is also known as Arthrophyllum reticulatum Blume ex Miq., Bignonia lugubris Salisb., Bignonia indica L., Bignonia tripinnata Noronha, Bignonia pentandra Lour., Bignonia quadripinnata Blanco, Bignonia tuberculate Roxb. ex DC., Hippoxylon indica (L.) Raf., Calosanthes indica (L.) Blume, Oroxylum flavum Rehder, and Spathodea indica (L.) Pers. Oroxylum indicum is commonly known as the tree of Damocles in English and Sonapatha or Shyonak in Hindi. Sonapatha is a semi-deciduous tree, which is sparingly branched and grows up to a height of $18-20 \mathrm{~m}$. The trunk of Sonapatha is around $40 \mathrm{~cm}$ in diameter, and the stem bark is light brown or greyish-brown colored, which is soft and spongy with numerous corky lenticels. The inner bark layer of Sonapatha is golden-yellow colored and, hence, the name Sonapatha [1-3]. The leaves of Sonapatha are crowded, 0.5-2 m long, 3-4 times pinnate with long petiole, and swollen rachis at the points of insertion (Figure 1). The stipules are absent, whereas leaflets are ovate to oblong. The leaflets are $4-15 \mathrm{~cm} \times 3-9 \mathrm{~cm}$ in size with a cuneate base 
and scattered glands on the lower surface. Inflorescence of Sonapatha is an erect raceme, terminal, and $25-150 \mathrm{~cm}$ long, with partitioned peduncle rachis (Figure 1). Flowers are bisexual, containing 2-4 cm long pedicel, bracteolate, coriaceous calyx, and campanulate. The buds are $2-4 \mathrm{~cm}$ long, $1.5-2 \mathrm{~cm}$ in diameter, brown or dirty violet colored, containing water, and become almost woody in fruit (Figure 1). The corolla is funnel shaped, about $10 \mathrm{~cm}$ long with 5 lobes, subequal with wrinkled margin, reddish outside, and yellowish to pinkish colored inside. The flowers contain five stamens, inserted in the throat, hairy at the base. The ovary is superior, two-celled, and contains many ovules (Figure 1).
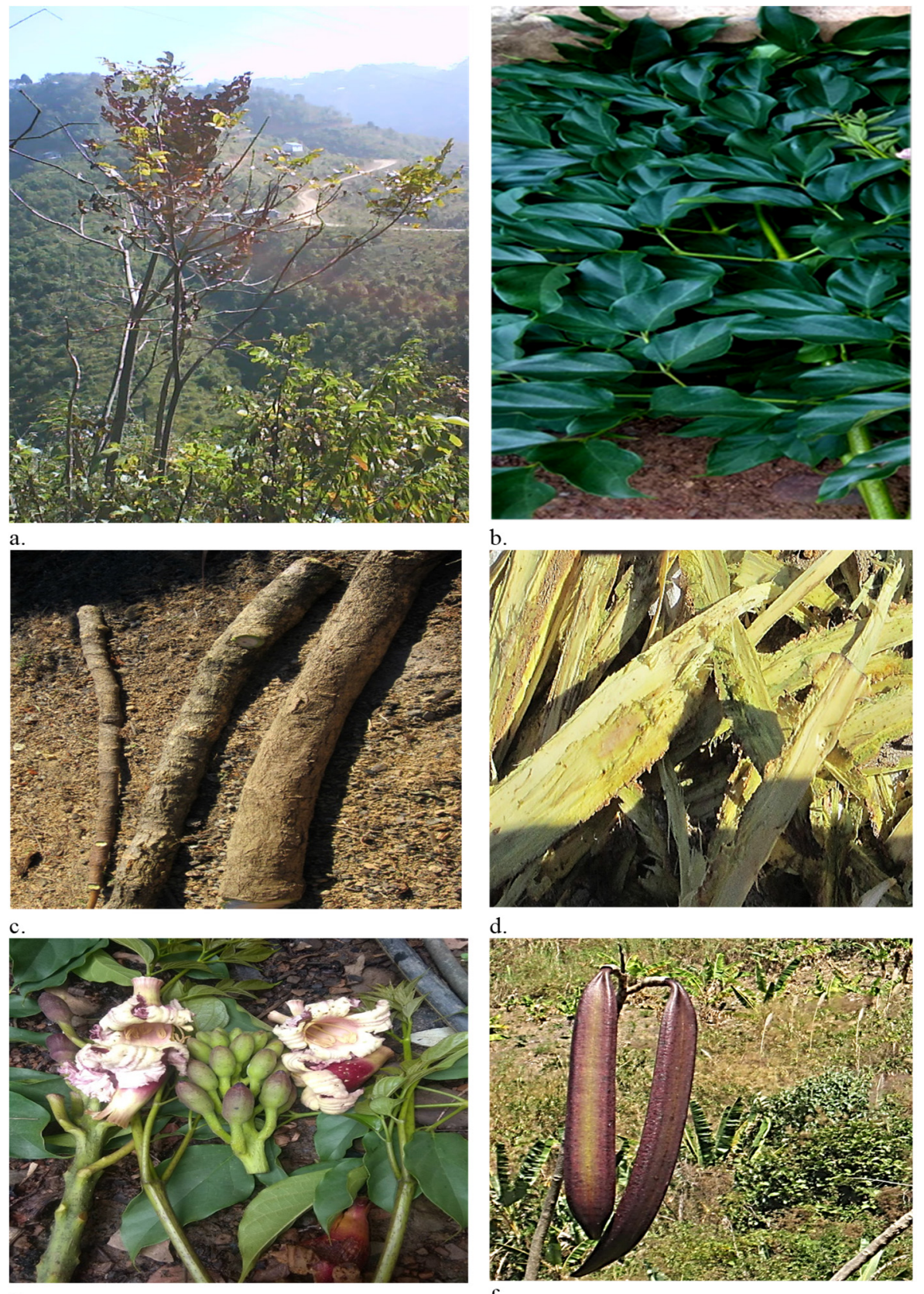

f

Figure 1. Oroxylum indicum: (a): whole tree; (b): leaves; (c): stem; (d): stem bark; (e): flowers; (f): fruits.

\section{Vernacular Names}

The different names of Sonapatha are listed in Table 1. It is commonly known as midnight horror, Indian trumpet flower, broken bones plant, Tree of Damocles, Indian calosanthes, Indian caper, and Indian trumpet in English; Shyonak, Sonapatha, Patrorna, 
Shallaka, Putivriksha, Shuran, Sauna, Son, Aralu, Vatuk, Urru, Bhut-Vriksha, Dirghavrinta, Kutannat, or Manduk (the flower) in Hindi; Shyonaka, Nat, Katvanga, Sukanasa, Prithu Simba, Tuntuka, Dirghavrinta, Mandukparana, Kutannata, Patroma, Katammar, Bhalluka, Mayurjangha, and Aralu in Sanskrit; Tentu in Gujarati; Ane-mungu, Alangi, Patagani, Bunepaale, Tattuna, Sonepatta, Tigadu, and Tattuna in Kannada; Dundilamu, Mandukaparamu, Chettu, Nemali, Pampena, Pampini, or Suka-nasamu in Telugu; Khonha, Sona, Kani-Dingi, Paharijora, Hanghoal, Thona Gach, Aklong-Singh, Krong-Sa-Bang (Marma Tribe), Naori Chilana (Chakma Tribe), Kaak-Rakung (Halam Tribe), Tou-Kharung (Tripura Tribe), or Kanai Dingi (Garo Tribe) in Bengali; Davamadak in Konkani; Achi, Arandei, Cori-Konnai, Venga maram, Palai-yutaicci, Pana, Puta-Puspam (the flower), Pei-maram, Peiarlanke, Palagaipayani, Peruvaagai or Vangam in Tamil; Tetu or Tayitu in Marathi; Vashrppathiri, Palaqapayyani, or Vellapathiri, in Malayalam; Bhatghila, Dingdinga or Toguna in Assamese; Archangkawm, Phanphania, or Tatelo in Oriya; Archangkawm in Mizo. Handy pinyin or Mud huddle in Chinese; Tatelo in Nepalese; Thotila or Totila in Singhalese; Bonglai Kulai or beka in Malay [1-6]. It is known as Pongporang (Sundanese), Kayu lanang, or Mungli (Javanese) in Indonesia; pingka-pingkahan (Tagalog), abong-abong (Bisaya), or Kamkampilan (Iloko) in Philippines; Pi ka in Cambodia; Lin may or Ung ka in Laos; Phe kaa (central), Litmai (northern), or Lin faa (north-eastern) in Thailand, and Núc nác, Hoàng bá nam, or Mộc hồ diệp in Vietnam [6-8].

Table 1. Common names of Oroxylum indicum in different languages.

\begin{tabular}{|c|c|c|}
\hline Language & Common Names & References \\
\hline English & $\begin{array}{c}\text { Midnight horror, Indian trumpet flower, broken bones plant, Tree of Damocles, } \\
\text { Indian calosanthes, Indian caper, Indian trumpet }\end{array}$ & {$[1-3,5]$} \\
\hline Hindi & $\begin{array}{c}\text { Shyonak, Sonapatha, Patrorna, Shallaka, Putivriksha, Shuran, Sauna, Son, Aralu, } \\
\text { Vatuk, Urru, Bhut-Vriksha, Dirghavrinta, Kutannat }\end{array}$ & {$[1-3,5]$} \\
\hline Sanskrit & $\begin{array}{l}\text { Shyonaka, Nat, Katvanga, Sukanasa, Prithu Simba, Tuntuka, Dirghavrinta, } \\
\text { Mandukparana, Kutannata, Patroma, Katammar, Bhalluka, Mayurjangha, Aralu }\end{array}$ & {$[1-3,5]$} \\
\hline Gujarati & Tentu & {$[1-3,5]$} \\
\hline Kannada & Ane-mungu Patagani, Bunepaale, Sonepatta, Tigadu, Alangi, and Tattuna & {$[1-3,5]$} \\
\hline Telugu & $\begin{array}{l}\text { Dundilamu, Manduka-paramu, Chettu, Nemali, Pampena, Pampini, Suka-nasamu } \\
\text { Khonha, Sona, Kani-Dingi, Paharijora, Hanghoal, Thona Gach, Aklong-Singh, }\end{array}$ & {$[1-3,5]$} \\
\hline Bengali & $\begin{array}{l}\text { Krong-Sa-Bang (Marma Tribe), Naori Chilana (Chakma Tribe), Kaak-Rakung } \\
\text { (Halam Tribe), Tou-Kharung Tripura Tribe), Kanai Dingi (Garo Tribe) }\end{array}$ & {$[1-3,5]$} \\
\hline Konkani & Davamadak & {$[1-3,5]$} \\
\hline Tamil & $\begin{array}{l}\text { Achi, Arandei, Cori-Konnai, Venga maram, Palai-yutaicci, Pana, Puta-Puspam (the } \\
\text { flower), Pei-maram, Peiarlanke, Palagaipayani, Peruvaagai or Vangam }\end{array}$ & {$[1-3,5]$} \\
\hline Marathi & Tetu, Tayitu & {$[1-3,5]$} \\
\hline Assamese & Bhatghila, Dingdinga, or Toguna & {$[1-3,5]$} \\
\hline Malayalam & Vashrppathiri, Palaqapayyani, or Vellapathiri & {$[1-3,5]$} \\
\hline Oriya & Archangkawm, Phanphania, Tatelo & {$[1-3,5]$} \\
\hline Chinese & Handy pinyin, Mud huddle & {$[1-3,5]$} \\
\hline Nepalese & Tatelo & {$[1-3,5]$} \\
\hline Singhalese & Thotila, Totila & {$[1-3,5]$} \\
\hline Malay & Bonglai & {$[1-3,5,6]$} \\
\hline Sundanese Javanese & $\begin{array}{l}\text { Pongporang } \\
\text { Kayu lanang, Mungli }\end{array}$ & [6-8] \\
\hline Filipino & Pingka-pingkahan (Tagalog), Abong-abong (Bisaya), Kamkampilan (Iloko) & [6-8] \\
\hline Khmer & Pi ka & {$[6-8]$} \\
\hline Lao & Lin may, Ung ka & [6-8] \\
\hline Thai & Phe kaa (central), Litmai (northern), Lin faa (north-eastern) & [6-8] \\
\hline Vietnamese & Núc nác, Hoàng bá nam, Mộc hồ diệp & [6-8] \\
\hline
\end{tabular}

\section{Geographical Distribution}

Sonapatha is distributed throughout the Indian subcontinent except drier regions and in the foothills of Himalaya up to a height of 1000-1200 m including Bhutan and Nepal. It is also widely distributed in Eastern and the Western Ghats as well as the North- 
East region of India [9]. In China, it grows in Fujian, Guangdong, Guangxi, Guizhou, Sichuan, and Yunnan provinces. Sonapatha is also found in Taiwan, Cambodia, Malaysia, Myanmar, Philippines, Thailand, Indonesia (Java, Sumatra), Sri Lanka (Ceylon), Vietnam, and Laos $[4,8,10]$.

\section{Traditional Medicinal and Ethnomedicinal Uses}

Natural products have played a crucial role in the healthcare of humans since their evolution and continue to play an important role even in the most modern state-of-the-art therapeutic era. The sword-like fruits or twigs of Sonapatha have been used by the farmers to kill crabs in the paddy fields. Its flowers and fruits are served as a vegetable in Thailand. It is also used as wood, tannins, and dye. Sonapatha is grown as an ornamental plant because of its strange looks [11]. The stem bark of Sonapatha is employed to kill maggots on cattle wounds [11-14]. Sonapatha has been used to treat several human ailments since ancient times. Various parts of Sonapatha are used for human healthcare traditionally and in Ayurveda, where it is one of the most important ingredients of Brahma Rasayana, Dashmularishta, Dhanawantara Ghrita, Amritarishta, Narayana Taila, Dantyadyarista, and Chyavanprasha $[11,15,16]$. Ayurveda classifies Sonapatha as shothara (anti-inflammatory); sheetha prashamana (subsides cough and cold), and anuvasanogapa (used as oil enema). Ayurveda describes Sonapatha as astringent, bitter, aphrodisiac, tonic, cooling, light to digest, dry, pungent, hot in potency, and an appetite booster. Sonapatha is given to treat "vata", asthma, bronchitis, fevers, diarrhea, dysentery, vomiting, biliousness, inflammation, leukoderma, skin diseases, rheumatoid arthritis, and to heal wounds. It is also given to deworm the intestine and to soothe anal troubles. Roots of Sonapatha act as an aphrodisiac, antidiabetic, astringent, antiarthritic, carminative, diaphoretic, constipating, anthelmintic, febrifuges, diuretic, digestive, and expectorant $[1,3,11,15]$. The root bark paste of Sonapatha prepared in sesame oil (Sesamum indicum) is a digestive tonic, whereas seeds are given orally to treat throat complications and hypertension [17]. The root bark of Sonapatha is given to treat nasopharyngeal cancer, stomatitis, and tuberculosis [18,19]. Sonapatha root bark paste is orally administered to treat dysentery, diarrhea jaundice, and rheumatism by the Naga tribe in India [20]. The medicated oil prepared from Sonapatha relieves pain in the otis when instilled in the ear [5]. Sonapatha seeds are digestive and purgative, and their paste is topically applied to treat boils and wounds. The powdered seeds are given to induce conception in women. The paste made from grounded seeds with fire soot is applied to the neck to treat tonsillitis. The poultice made from the bark of Sonapatha is used in the treatment of inflammations, skin diseases, sprains, and rheumatism, whereas powdered bark and paste are applied on burns and wounds, respectively $[13,14,21]$. Sonapatha stem bark is also used to treat stomach disorders [22]. A glass of bark decoction with two spoons of sugar is often given to cure jaundice by the halam tribe of northeast India [23]. The leaves are used in the snakebite and to treat ulcers, headache, and enlarged spleen $[14,19,24]$. Sonapatha fruits are sweet in taste, acrid, anthelmintic, stomachic, and expectorant and are used to improve appetite, treat throat infection, bronchitis, heart disorders, leukoderma, and piles [15,19,24-26]. The seeds and bark of Sonapatha are given in conditions of pneumonia, respiratory troubles, and fever by different tribes in India [27,28].

The root decoction of Sonapatha is given in the conditions of dysentery and diarrhea in Nepal [29]. In Malaysia, Sonapatha is given to relieve toothache, treat cholera, dysentery, fever, gastralia, wound injury, splenomegaly, and loss of appetite. The decoction prepared from any part of Sonapatha is used externally during childbirth. The fresh bark of Sonapatha is macerated and applied topically in allergic dermatitis. In the Philippines, the root bark is used as a diaphoretic [30]. In Vietnam, seed decoction is used as a folk medicine to cure bronchitis, cough, and gastritis. In Chinese medicine, the seeds of Sonapatha are given to treat ulcers, boils, liver, and stomach problems. Sonapatha bark is used in the treatment of rheumatism and dysentery in Myanmar, the Philippines, and Vietnam [31]. 


\section{Phytochemistry}

Table 2 lists various phytochemicals that have been detected in Sonapatha. The chloroform and ethanol stem bark extracts of Sonapatha contained phenolics and flavonoids, whereas saponins in the aqueous extract. The alkaloids were detected in benzene, chloroform, and ethanol extracts [32]. The ethyl acetate fractions of Sonapatha stem and root bark extracted in methanol and water (4:1) showed the presence of glycosides, terpenoids phenols, and alkaloids [33]. The seeds of Sonapatha extracted in acetone, benzene, chloroform, methanol, and water showed the presence of alkaloids, flavonoids, tannins, glycosides, sterols, phenols, saponins, fats, and oils, whereas alkaloids, glycosides, flavonoids, lignins, and quinines were absent in the chloroform seed extract. Acetone, benzene, chloroform, and methanol extracts of Sonapatha stem bark showed the presence of tannins, saponins, sterols, phenols, fats, and oils, whereas glycosides and quinones were absent in all extracts of stem bark. The methanol extract of the bark was weakly positive for alkaloids. The root bark of Sonapatha extracted in acetone, benzene, chloroform, methanol, and water showed the presence of flavonoids, alkaloids, glycosides, tannins, sterols, phenols, lignins, saponins, fats, and oils; however, quinones were absent [34]. The alkaloids, flavonoids, tannins, and glycosides were detected in the $95 \%$ ethanol extract of Sonapatha [35]. Chloroform and ethanol extracts of Sonapatha stem bark showed the presence of alkaloids. The flavonoids and tannins were detected in the chloroform, ethanol, and aqueous extracts, whereas cardiac glycosides were detected only in chloroform and ethanol extracts. The saponins were present only in ethanol and aqueous extracts of Sonapatha and the steroids were absent in the latter. The phlobatannins were altogether absent in Sonapatha stem bark [13]. The methanol extract of tender leaves of Sonapatha has been reported to possess phlobatannins, flavonoids, phenols, tannins, and glycosides [36].

Table 2. Different phytoconstituents detected in the Oroxylum indicum.

\begin{tabular}{|c|c|c|c|}
\hline Plant Part & Extract Type & Phytoconstituents & Reference \\
\hline Stem bark & $\begin{array}{l}\text { Chloroform, ethanol aqueous } \\
\text { Benzene, chloroform, ethanol }\end{array}$ & $\begin{array}{l}\text { Phenolics, flavonoids, saponins } \\
\text { Alkaloids }\end{array}$ & {$[32]$} \\
\hline Stem and root bark & Hydromethanol & Glycosides, terpenoids phenols, alkaloids & [33] \\
\hline Seeds & Acetone, benzene, methanol, water & $\begin{array}{l}\text { Alkaloids, flavonoids, tannins, glycosides, } \\
\text { sterols, phenols, saponins, fats, oils }\end{array}$ & [34] \\
\hline Stem bark & $\begin{array}{l}\text { Acetone, benzene, chloroform, } \\
\text { methanol }\end{array}$ & Tannins, saponins, sterols, phenols, fats, oils & [34] \\
\hline Root bark & $\begin{array}{l}\text { Acetone, benzene, chloroform, } \\
\text { methanol, water }\end{array}$ & $\begin{array}{l}\text { Flavonoids, alkaloids, glycosides, tannins, } \\
\text { sterols, phenols, lignins, saponins, fats, oils }\end{array}$ & [34] \\
\hline Stem Bark & Ethanol & Alkaloids, flavonoids, tannins, glycosides & [35] \\
\hline Stem bark & $\begin{array}{l}\text { Chloroform, ethanol, water } \\
\text { Chloroform, ethanol, water }\end{array}$ & $\begin{array}{l}\text { Alkaloids, flavonoids, tannins } \\
\text { Cardiac glycosides, saponins }\end{array}$ & [13] \\
\hline Tender leaves & Methanol & $\begin{array}{l}\text { Phlobatannins, flavonoids, phenols and } \\
\text { tannins, glycosides }\end{array}$ & [36] \\
\hline
\end{tabular}

\subsection{Isolation of Active Chemicals}

Several chemicals have been isolated from different parts of Sonapatha (Table 3).

Table 3. Different active chemicals isolated from various parts of Oroxylum indicum.

\begin{tabular}{ccc}
\hline Parts & Isolated Chemical & Reference \\
\hline Leaves & $\begin{array}{c}\text { Chrysin, oroxylin-A, scutellarin, scutellarin, baicalein, baicalein-6-O-glucuronide, baicalein, } \\
\text { baicalein-7-O-glucoside, baicalein-7-O-diglucoside, baicalein-7-O-glucuronide, chrysin, } \\
\text { chrysin-diglucoside, chrysin-7-O-glucuronide, ar-tumerone, methyl hexadecanoate, } \\
\text { laurenan-2-one, isopropyl butanoate. }\end{array}$ \\
\hline
\end{tabular}


Table 3. Cont.

\begin{tabular}{|c|c|c|}
\hline Parts & Isolated Chemical & Reference \\
\hline Stem & $\begin{array}{l}\text { Oroxylin A, scutellarin, baicalein, baicalein-6-O- glucuronide, dihydrobaicalein, ellagic acid, } \\
\text { dihydrooroxylin-A, methyl-3,-4,5-trihydroxy-6-(5-hydroxy-6-methoxy-4-oxo-2- } \\
\text { phenylchroman-7-yloxy)-tetrahydro-2H-pyran-2-carboxylate, } \\
\text { 5-hydroxyl-7-methoxy-2-(2-methoxy-6-(3,4,5-trihydroxy-6-(hydroxymethyl)-tetrahydro-2H- } \\
\text { pyran-2-yoloxy)phenyl)-4H-chromen-4-one, chrysin, oroxylin A, oroxyloside, hispidulin, } \\
\text { apigenin, ficusal, balanophonin, 2-(1-hydroxy- } \\
\text { methylethyl)- } 4 \mathrm{H}, 9 \mathrm{H} \text {-naphtho[2,3-b]furan-4,9-dione, salicylic acid, } \rho \text {-hydroxybenzoic acid, } \\
\text { protocatechuic acid, isovanillin, } \beta \text {-hydroxypropiovanillon, baicalein, oroxylin, pinostrobin, } \\
\text { stigmast-7-en-3-ol, 3,4',5,7 tetrahydroxy flavonol (kaempferol), } \\
\text { 5,6,7-trimethoxyflavone-8-O- } \beta \text {-D-glucopyranoside, oroxylin A-7-O- } \beta \text {-D-glucuronide butyl } \\
\text { ester, 6-methoxy-baicalein, oroxylin-A-7-O-glucoside, 5,7-dihydroxyflavone, baicalein } \\
\text { 6-methoxy-7-glucuronide, dehydro-iso- } \alpha \text {-lapachone, lapachol. }\end{array}$ & {$[6,14,39-43]$} \\
\hline Root & $\begin{array}{c}\text { Ellagic acid, baicalein, chrysin, biochanin-A, oroxylin A, baicalein, hispidulin, } \\
\text { 2,5-dihydroxy-6,7-dimethoxy flavone, 3,7,3', } 5^{\prime} \text {-tetra- methoxy-4-hydroxy flavone, lapachol, } \\
\beta \text {-sitosterol }\end{array}$ & {$[6,44-46]$} \\
\hline Seeds & 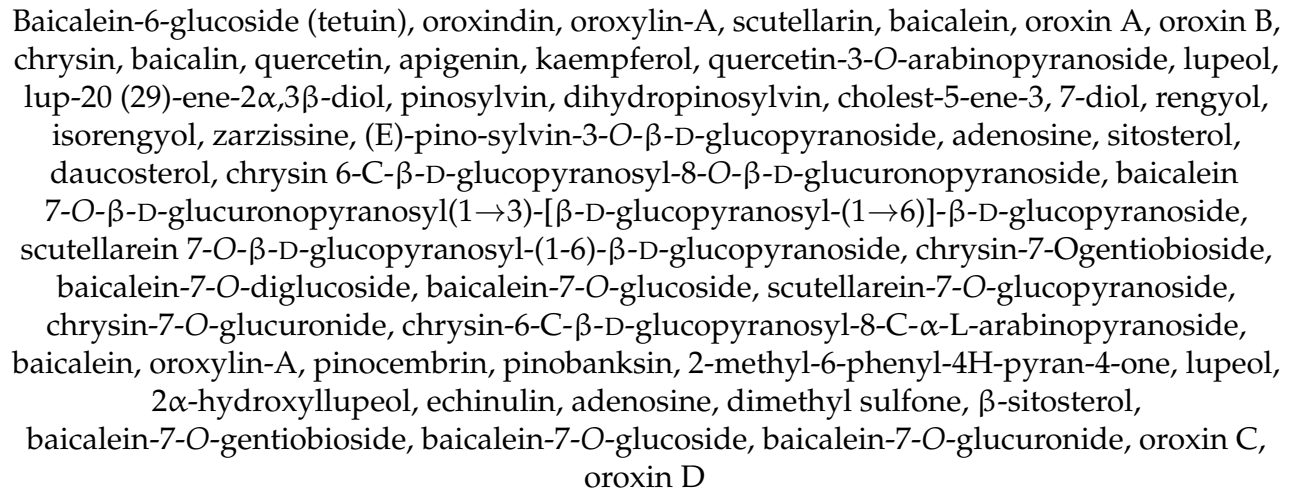 & [47-54] \\
\hline Flower & Baicalein, chrysin & [55] \\
\hline Fruit & Oroxylin A, orlumin A, chrysin, ursolic acid & {$[56,57]$} \\
\hline
\end{tabular}

\subsubsection{Leaf}

The leaves of Sonapatha contained baicalein; baicalein-7-O-glucoside; baicalein7-O-diglucoside; baicalein-7-O-glucuronide; chrysin; chrysin-diglucoside; chrysin-7-Oglucuronide; oroxylin-A; scutellarin; baicalein-6-0-glucuronide [37]. The leaf oil of Sonapatha showed the presence of Ar-tumerone, methyl hexadecanoate, aurenan-2-one, and isopropyl butanoate [38].

\subsubsection{Stem}

Oroxylin A, chrysin, scutellarin, baicalein, baicalein-6-O-glucuronide, dihydrobaicalein, ellagic acid, dihydrooroxylin-A, methyl-3,4,5-trihydroxy-6-(5-hydroxy-6-methoxy-4-oxo2-phenyl-chroman-7-yloxy)-tetrahydro-2H-pyran-2-carboxylate, 5-hydroxyl-7-methoxy-2(2-methoxy-6-(3,4,5-trihydroxy-6-(hydroxymethyl)tetrahydro-2H-pyran-2-yoloxy)phenyl)$4 \mathrm{H}$ - chromen-4-one, or-oxyloside, hispidulin, apigenin, ficusal, balanophonin, 2-(1hydroxymethylethyl)-4H, 9H-naphtho [2,3- $\beta$ ]furan-4,9-dione, salicylic acid, $\rho$-hydroxybenzoic acid, protocatechuic acid, isovanillin, $\beta$-hydroxypropiovanillon, oroxylin, pinostrobin, stigmast-7-en-3-ol, and 3,4',5,7 tetra-hydroxy flavonol (kaempferol), dehydro-iso- $\alpha$-lapachone, and lapachol were isolated from the stem of Sonapatha [6,14,39-42]. Additionally, 5,6,7trimethoxy flavone-8-O- $\beta$-D-glucopyranoside, oroxylin A-7-O- $\beta$-D-glucuronide butylester, 6-methoxy-baicalein, oroxylin-A-7-O-glucoside, 5,7-dihydroxy-flavone, baicalein, and 6-methoxy-7-glucuronide have also been separated from the stem of Sonapatha [6,14,39-43]. 


\subsubsection{Roots}

The roots of Sonapatha have been reported to contain ellagic acid, baicalein, chrysin, biochanin-A, oroxylin A, hispidulin, 2,5-dihydroxy-6,7-dimethoxy flavone and 3,7, 3', 5' tetramethoxy-4-hydroxy flavone, lapachol, and $\beta$-sitosterol [6,44-46].

\subsubsection{Seeds}

Several phytochemicals have been isolated from seeds of Sonapatha including oroxylinA, scutellarin, baicalein, oroxindin, baicalein-6-glucoside (tetuin), oroxin A, oroxin B, chrysin, baicalin, quercetin, apigenin, kaempferol, quercetin-3-O-ara-binopyranoside, lupeol, lup-20 (29)-ene-2 $\alpha, 3 \beta$-diol, pinosylvin, dihydropinosylvin, cholest-5-ene-3, 7-diol, rengyol, isorengyol, zarzissine, (E)-pinosylvin-3-O- $\beta$-D-glucopyranoside, adenosine, sitosterol, daucosterol, chrysin 6-C- $\beta$-D-glucopyranosyl-8-O- $\beta$-D-glucuronopyranoside, baicalein 7-O- $\beta$ D-glucuronopyranosyl-( $1 \rightarrow 3)[\beta$-D-glucopyranosyl $(1 \rightarrow 6)] \beta$-D-glucopyranoside, scutellarin 7-O- $\beta$-D-glucopyranosyl-(1-6)- $\beta$-D-glucopyranoside, chrysin-7-O-gentiobioside, baicalein7-O-diglucoside, baicalein-7-O-glucoside, scutellarin-7-O-glucopyranoside, 2-methyl-6-phenyl $4 \mathrm{H}$-pyran-4-one, chrysin-7-O-glucuronide, chrysin-6-C- $\beta$-D-dimethyl sulfone, glucopyranosyl8 -C- $\alpha$-L-arabinopyranoside, pinocembrin, pinoban- ksin, lupeol, $2 \alpha$-hydroxyllupeol, echinulin, $\beta$-sitosterol, baicalein-7-O-gentiobioside, baicalein-7-O-glucoside, baicalein-7-O-glucuronide, oroxin C, and oroxin D [47-54].

\subsubsection{Flowers and Fruits}

Baicalein and chrysin have been isolated from the flowers of Sonapatha [55], whereas the fruits have been shown to possess oroxylin A, orlumin A, chrysin, and ursolic acid [56,57].

\section{Pharmacological Activities}

Sonapatha has shown various pharmacological activities in different study systems in vitro and in vivo as listed below.

\subsection{Free Radical Scavenging and Antioxidant Activities}

Table 4 lists the free radical scavenging ability of various extracts of Sonapatha. The estimation of antioxidant activity by reduction in $\mathrm{Mo}^{+4}$ to $\mathrm{Mo}^{+5}$ showed that petroleum ether, benzene, chloroform, ethanol, and aqueous stem bark extracts of Sonapatha dose dependently increased the antioxidant activity, and the highest antioxidant potential was detected for the chloroform followed by ethanol extract, whereas the petroleum ether extract was the least active [32]. The methanol extract of different parts of Sonapatha also scavenged hydroxyl, nitric oxide, superoxide, and DPPH free radicals in vitro [58]. The leaves of Sonapatha extracted in petroleum ether, chloroform, ethanol, and water inhibited the formation of DPPH, hydroxyl, nitric oxide, and superoxide radicals concentration dependently, where the ethanol extract was most potent. The reducing power assay further confirmed that the ethanol leaf extract of Sonapatha was more powerful than the other extracts [59]. Similarly, leaves of Sonapatha extracted in ethyl acetate, methanol, and water scavenged DPPH radical depending on their concentration, and the ethyl acetate extract was most potent followed by methanol and water extracts [60]. The hexane, chloroform, ethyl acetate, and water extracts of stem bark of Sonapatha showed a concentration-dependent inhibition of DPPH radicals, and the ethyl acetate extract was more effective than the other three extracts [61]. The petroleum ether, dichloromethane, and methanol extracts of Sonapatha have been found to scavenge DPPH, and superoxide radicals and possessed $\mathrm{Fe}^{3+}$ reducing potential. The methanol extract was more potent than the other two extracts [62]. The radical scavenging activity of chloroform, ethanol, and aqueous extracts of the stem bark of Sonapatha showed that it inhibited DPPH, superoxide anion, hydroxyl, and nitric oxide free radicals in a concentration-dependent manner, and $200 \mu \mathrm{g} / \mathrm{mL}$ of chloroform and ethanol extracts scavenged the DPPH radicals to the maximum extent. This concentration for hydroxyl radical inhibition was 6000 and $8000 \mu \mathrm{g} / \mathrm{mL}$ for chloroform and ethanol 
extracts, respectively. The highest scavenging of superoxide anion radical was observed at a concentration of $2500 \mu \mathrm{g} / \mathrm{mL}$ for both chloroform and ethanol extracts, whereas it took $20,000 \mu \mathrm{g} / \mathrm{mL}$ to inhibit the nitric oxide radical to the maximum extent. The ferric reducing power of different Sonapatha stem bark extracts increased depending on their concentration and a dose of $2500 \mu \mathrm{g} / \mathrm{mL}$ of all three extracts resulted in the maximum reduction in ferric iron [63]. The ethanol and aqueous extracts of Sonapatha seeds have been reported to inhibit DPPH radicals, whereas the fruit extracts were less effective than the seed extracts [64].

Table 4. Free radical scavenging and antioxidant activity of Oroxylum indicum.

\begin{tabular}{cccc}
\hline Plant Part & Activity Type & Reference \\
\hline $\begin{array}{c}\text { Stem bark } \\
\text { Root/root bark, stem/stem }\end{array}$ & Antioxidant & [32] \\
bark, leaf, fruit & Hydroxyl, nitric oxide, superoxide, DPPH radical scavenging & [58] \\
Leaf & DPPH, nitric oxide, superoxide, hydroxyl radical scavenging, reducing power & {$[59,60]$} \\
Stem Bark & DPPH, nitric oxide, superoxide, hydroxyl radical scavenging, reducing power & [32,61-63] & DPPH \\
Seed & & & [64] \\
\hline
\end{tabular}

\subsection{Anti-Inflammatory and Analgesic Activities}

The $50 \mu \mathrm{g} / \mathrm{mL}$ of dichloromethane root extracts of Sonapatha resulted in 100\% inhibition of leukocyte lipoxygenase activity indicating its anti-inflammatory potential [6]. The aqueous leaf extract of Sonapatha has shown anti-inflammatory activity in carrageenaninduced rat paw edema test where $300 \mathrm{mg} / \mathrm{kg}$ body weight (b. wt.) extract was found to be superior over $150 \mathrm{mg} / \mathrm{kg} \mathrm{b}$. wt. [65]. A similar effect has been reported for the Sonapatha root and stem bark decoction in water that reduced the carrageenan-induced rat paw edema [66]. The rats treated with aqueous root extract of Sonapatha at a dose of 100,200 and $400 \mathrm{mg} / \mathrm{kg} \mathrm{b}$. wt. for seven or four days significantly inhibited the induction of dinitrobenzene sulfonic acid-induced colitis [67]. The oral administration of $500 \mathrm{mg} / \mathrm{kg}$ b. wt. reduced acetic acid writhing, which was comparable to standard analgesic agent aminopyrine given at a dose of $50 \mathrm{mg} / \mathrm{kg}$ [68]. The aqueous extract of Sonapatha has been reported to reduce mouse ear edema in an earlier study [69]. The ethanol extract of Sonapatha ( 250 and $300 \mathrm{mg} / \mathrm{kg}$ b. wt.) was evaluated for its anti-inflammatory and analgesic activities and $300 \mathrm{mg} / \mathrm{kg}$ ethanol extract reduced mice ear and paw edema and also exerted analgesic effect to the maximum extent [70]. The hydroalcoholic extract of Sonapatha stem bark extract exerted anti-inflammatory activity on carrageenan-induced rat paw edema [71]. The Sonapatha extracted in methanol and given at a dose of 100, 200 , and $400 \mathrm{mg} / \mathrm{kg} \mathrm{b}$. wt. has been reported to reduce carrageenan-induced rat paw edema depending on its dose. The histological evaluation of rat paw showed reduced cell infiltration and suppressed inflammation in a dose-dependent manner [72].

\subsection{Anti-Allergic and Antiasthmatic Effect}

Allergic rhinitis and asthma are linked and affect $40 \%$ of the world population. They reduce the quality of life and performance and their prevalence has been increasing in the population throughout the world [73]. The studies on the antiallergic and antiasthmatic effect of Oroxylum indicum are scanty. The antiallergic and anti-asthmatic effects of oroxylin A extracted from Sonapatha have been studied in female Balb/c mice and cultured rat RBL$2 \mathrm{H} 3$ mast cells. The rat RBL-2H3 mast cells sensitized with monoclonal anti-dinitrophenyl specific mouse IgE and then exposed to $0.1,0.3,1,3,10$, and $30 \mu \mathrm{M}$ oroxylin A reduced the antigen-induced degranulation in a concentration-dependent manner as indicated by the release of $\beta$-hexosaminidase. The maximum degranulation and $\beta$-hexosaminidase release were estimated at a concentration of $30 \mu \mathrm{M}$ oroxylin A in RBL-2H3 mast cells. The female $\mathrm{Balb} / \mathrm{c}$ mice were injected with 1 and $5 \mathrm{mg} / \mathrm{kg}$ b. wt. oroxylin A intraperitoneally 30 before OVA administration to induce asthma inhibited the accumulation of eosinophils in bronchoalveolar lavage fluid of mice by $51 \%$ and $84 \%$, respectively. The histologic observa- 
tions of mice lungs revealed the accumulation of eosinophils around bronchioles whereas oroxylin A administration alleviated the eosinophils around bronchioles depending on its dose. The oroxylin A administration also reduced the OVA-induced mucin production in the mice lungs. The study on various cytokine expression revealed that oroxylin $\mathrm{A}$ suppressed the expression of IL-4, IL-5, and IL-13, INF- $\gamma$ and IL-2 in the lungs of OVA administered mice, which may be responsible for its antiallergic and antiasthmatic activities in Balb/c mice [74].

\subsection{Antimicrobial Activity}

The antimicrobial activity of the dichloromethane extract of Sonapatha was studied against the Gram-positive and Gram-negative bacteria, and it was found to inhibit the growth of both the Gram-positive Bacillus subtilis and Staphylococcus aureus and the Gram-negative Escherichia coli and Pseudomonas aeruginosa bacteria and the fungi Candida albicans [6]. The dichloromethane extract of Sonapatha also inhibited the growth of dermatophytes and wood root fungi [75]. The root and stem of Sonapatha extracted in alcohol suppressed the growth of Klebsiella, Escherichia coli, Proteus, Pseudomonas, and Staphylococcus aureus, and the stem extract was found to be superior to the root extract [33]. The methanol extract of stem bark of Sonapatha has been reported to be active against Bacillus cereus, Bacillus megaterium, Bacillus subtilis, Staphylococcus aureus, Sarcina lutea (Gram-positive), Escherichia coli, Pseudomonas aeruginosa, Salmonella paratyphi, Salmonella typhi, Shigella boydii, Shigella dysenteriae, Vibrio mimicus, Vibrio parahemolyticus (Gram-negative), and the fungi Saccharomyces cerevisiae, Candida albicans and Aspergillus niger [42].

The petroleum, ether, dichloromethane, and methanol extracts of stem bark of Sonapatha were active against the Klebsiella pneumoniae, Pseudomonas aeruginosa, Escherichia coli, Bacillus subtilis, Bacillus cereus, and Staphylococcus aureus bacteria and Aspergillus flavus, Aspergillus fumigatus, and Macrofomina phaeolina fungi [62]. The hydroalcoholic extract of stem bark of Sonapatha reduced the growth of Bacillus cereus, Bacillus subtilis, Staphylococcus aureus, and Staphylococcus albus bacteria [76]. The aqueous extracts of Sonapatha seeds and fruits have been reported to inhibit the growth of Staphylococcus intermedius and Streptococcus suis bacteria in a concentration-dependent manner and the aqueous extract was less effective. The seed extracts were more effective than the fruit extracts [36]. The stem bark of Sonapatha extracted in methanol, ethyl acetate and ethanol inhibited the growth of Bacillus subtilis, Escherichia coli (Gram-positive), and Pseudomonas aeruginosa (Gram negative), and the ethanol extract was found to be most potent [77]. The hexane, chloroform, ethyl acetate, and water extracts of stem bark of Sonapatha have shown antimicrobial activity against Escherichia coli, Bacillus subtilis, Pseudomonas aeruginosa, Staphylococcus aureus, and Candida albicans. The chloroform and ethyl acetate extracts were most effective than the hexane and water extracts [61]. The tender leaves of Sonapatha extracted in methanol inhibited the growth of Pseudomonas aeruginosa and Bacillus subtilis studied by zone inhibition and well methods, respectively [36]. The orlumin A isolated from the fruits of Sonapatha has shown the highest antibacterial activity against methicillin-resistant Staphylococcus aureus (MRSA) with a MIC value of $3.1 \mu \mathrm{g} / \mathrm{mL}$ [57].

\subsection{Anthelmintic Effect}

The methanol extract of Sonapatha stem bark has been tested against the anthelmintic activity in Hymenolepis diminuta. The artificially excysted juveniles and adult $H$. diminuta worms were treated with 10, 20, and $30 \mathrm{mg} / \mathrm{mL}$ of stem bark Sonapatha decoction. The exposure of juvenile worms to $30 \mathrm{mg} / \mathrm{mL}$ of Sonapatha bark extract resulted in worm mortality as early as $0.25 \pm 0.00 \mathrm{~h}$ after treatment. The scanning electron microscopic examination revealed that the extract treatment led to wrinkled scolex, distorted integument, and eroded microtriches in both the juvenile and adult worms [78]. The in vivo study in $H$. diminuta infected Wistar rats revealed that administration of $1000 \mathrm{mg} / \mathrm{kg} \mathrm{b}$. wt. Sonapatha extract caused $79.3 \%$ reduction in eggs per gram of feces count and $70.8 \%$ reduction in worm counts indicating that it was more effective in killing juvenile worms than the adult 
worms [78]. A study of methanol extract of Sonapatha stem bark and aqueous fruit extracts was conducted against the killing of adult Pheretima posthuma earthworm. The exposure of $P$. posthuma to 10,50 , and $100 \mathrm{mg} / \mathrm{mL}$ of stem bark and fruit extracts of Sonapatha resulted in a concentration-dependent paralysis and death of earthworms depending on the concentration [79].

\subsection{Hepatoprotective Effect}

The hepatoprotective effect of petroleum ether, chloroform, ethanol, and aqueous extracts of Sonapatha leaves was studied against the carbon tetrachloride-induced liver toxicity. All four extracts protected the liver against the carbon tetrachloride-induced toxicity as indicated by a decline in the rat serum aspartate transaminase (AST) and alanine aminotransaminase (ALT) alkaline phosphatase (ALP) and total bilirubin levels. However, ethanol extract was found to be most effective than the other three extracts [59]. The administration of methanol stem bark extract of Sonapatha at a dose of $500 \mathrm{mg} / \mathrm{kg} \mathrm{b}$. wt. protected rat liver against the carbon tetrachloride-induced toxicity by reducing the serum AST, ALT, ALP, and total bilirubin levels. It also reduced carbon tetrachloride-induced rat liver damage and necrosis [80]. The hepatoprotective action of 100,200 , and $400 \mathrm{mg} / \mathrm{kg} \mathrm{b}$. wt. of aqueous root bark extract of Sonapatha was studied against the paracetamol-induced liver toxicity in Wistar rats, where the aqueous extract was found to reduce serum AST, ALT, and ALP levels in a dose-related manner, and their lowest activities were reported for $400 \mathrm{mg} / \mathrm{kg}$ extract. This was backed by histological examination where the aqueous Sonapatha root bark extract reduced the paracetamol-induced degenerative changes in the liver of Wistar rats [81]. The mouse treated with petroleum ether, ethyl acetate, methanol, and ethanol extracts of Sonapatha stem bark protected the liver against carbon tetrachlorideinduced liver toxicity. The ethyl acetate extract was superior to other extracts as it reduced the pathological damage to the liver to a maximum extent followed by the higher reduction in AST, ALT, ALP, and total bilirubin levels in mouse serum than the other extracts [23]. The methanol-dichloromethane extract of the whole Sonapatha plant has been reported to protect liver explant and chronic liver damage in rats as indicated by a significant depletion in AST, ALT, and ALP levels in both explant and rat serum. Besides, the serum bilirubin level declined significantly. The histology of the liver showed mild hepatic swelling and a reduction in the carbon tetrachloride-induced hepatic injury [82]. The administration of 10,50 , and $100 \mathrm{mg} / \mathrm{kg}$ b. wt. aqueous-methanol extract of stem bark of Sonapatha reduced the acetaminophen-induced liver toxicity in a dose-dependent manner, where the serum levels of AST, ALT, and lipid peroxidation (LOO) were significantly low in Sprague-Dawley rats [83]. The aqueous and ethanol extracts of Sonapatha protected Wistar rats against the antitubercular drug AKT-4 induced hepatotoxicity significantly by alleviating the AKT4 induced increase in ALT, AST, lactate dehydrogenase (LDH), and total bilirubin levels. Additionally, the aqueous and ethanol extracts of Sonapatha significantly increased catalase, superoxide dismutase (SOD), and glutathione (GSH) levels, whereas LOO level declined significantly in the AKT-4 treated rat liver. AKT4 induced pathological alterations in the hepatocytes of the rat with distorted hepatic cords, degenerative, and necrobiotic changes, accumulation of fat globules in the hepatocytes with their swelling and hemorrhage, whereas treatment of rats with aqueous and ethanol extracts of Sonapatha, showed no such histopathological changes in the liver [84]. The 70\% ethanol extract of stem bark of Sonapatha reduced serum, ALT, ALP, $\gamma$-glutamyltransferase (GGT), and total bilirubin levels at different posttreatment days in the carbon tetrachloride treated Wistar rats [85]. The seed extract of Sonapatha has been reported to protect against the progression of nonalcoholic fatty liver disease into nonalcoholic steatohepatitis in vitro and in vivo by inhibiting the transcriptional activity of NF- $\mathrm{KB}$ and its phosphorylation and increasing the nuclear factor of kappa light polypeptide gene enhancer in B-cells inhibitor (IKB) level [86]. 


\subsection{Gastroprotective Effect}

The gastroprotective activity of 100 and $300 \mathrm{mg} / \mathrm{kg} \mathrm{b}$. wt. of $50 \%$ hydroalcoholic, petroleum ether, chloroform, ethyl acetate, and n-butanol extracts of root bark of Sonapatha were studied against ethanol-induced gastric damage. All extracts at a dose of $300 \mathrm{mg} / \mathrm{kg}$ showed a significant reduction in the ulcer index. The petroleum ether, n-butanol, and chloroform extracts were most effective when compared to ethyl acetate and hydroalcoholic root extracts. Likewise, these extracts of Sonapatha also reduced LOO and increased the activities of SOD, and catalase, and GSH levels, especially at a dose of $300 \mathrm{mg} / \mathrm{kg}$ in Wistar rats [87]. Treatment of 100 and $250 \mathrm{mg} / \mathrm{kg}$ of hexane and acetone stem bark extracts of Sonapatha had a mild to moderate protective effect against different models of gastric ulcerations. The isolated chrysin and compound 1 from the stem bark of Sonapatha were superior gastroprotective agents in pylorus ligation and cold restrain-induced ulceritis models in rats [40]. The butanol, petroleum ether, and ethanol extracts of stem bark of Sonapatha reduced the ethanol-induced gastric ulcers with an inhibitory index of $0.07 \pm 0.007(99 \%), 0.27 \pm 0.011(96 \%)$, and $0.87 \pm 0.044(86 \%)$, respectively [72].

\subsection{Cardioprotective Effect}

The cardioprotective effect of $70 \%$ methanol extract of root bark of Sonapatha was studied in doxorubicin-treated Sprague Dawley rats. The oral administration of animals with 200 and $400 \mathrm{mg} / \mathrm{kg} \mathrm{b}$. wt. Sonapatha extract for 14 days protected rats against doxorubicin-induced cardiotoxicity. The methanol extract of Sonapatha led to normalization of Electrocardiogram (ECG), ST-segment depression, and QRS complex in the hearts of doxorubicin treated rats. The serum marker enzymes like creatinine phosphokinase (CPK), AST, and LDH were significantly reduced by methanol extract of Sonapatha. The assessment of LOO, GSH, glutathione peroxidase, (GPx), and SOD in the heart tissue revealed a significant decline in LOO and rise in the GSH, GPx, and SOD levels in the Sonapatha treated group when compared to doxorubicin treatment alone. Histopathologic evaluation revealed focal degeneration, fragmentation, disorganization of myofibrils, and necrotic changes in the heart tissue after doxorubicin treatment whereas Sonapatha extract administration reduced these changes [88].

\subsection{Antidiabetic Effect}

Administration of 300 and $500 \mathrm{mg} / \mathrm{kg} \mathrm{b}$. wt. of aqueous and ethanol extracts of Sonapatha for 21 days significantly reduced serum glucose levels in alloxan and dexamethasoneinduced diabetes in Wistar rats [89]. Methanol extract of the heartwood of Sonapatha reduced the activity of $\alpha$-glucosidase (GAA; an enzyme involved in carbohydrate digestion and glycoprotein biosynthesis, which is highly activated in diabetes) indicating its antidiabetic potential [41]. Similarly, hydroalcoholic extract ( $50 \%$ ethanol) of Sonapatha inhibited GAA activity in vitro. Sonapatha extract has been found to improve insulin sensitivity in cultured 3T3-L1 mature adipocytes. Oral administration of $250 \mathrm{mg} / \mathrm{kg}$ b. wt. of $50 \%$ ethanol extract of Sonapatha has reduced fasting blood glucose, low-density lipoprotein (LDL), and glycosylated hemoglobin ( $\mathrm{HbA} 1 \mathrm{c})$ levels and elevated high-density lipoprotein (HDL) in streptozotocin-induced diabetic rat serum after 28 days post-treatment. Homeostasis model assessment-insulin resistance (HOMA-IR) index and quantitative insulin sensitivity check index (QUICKI) were also significantly reduced in Sonapatha treated diabetic rats after 28 days post-treatment [90]. The seeds of Sonapatha extracted in $90 \%$ ethanol inhibited the rat intestinal GAA activity. The administration of 50 and $250 \mathrm{mg} / \mathrm{kg}$ b. wt. of alcoholic seed extract of Sonapatha non-significantly reduced the fasting glucose level in alloxan-induced diabetic mice however, its combination with acarbose significantly reduced the fasting glucose level [91]. Similarly, $90 \%$ ethanol seed extract of Sonapatha at a dose of 50 and $200 \mathrm{mg} / \mathrm{kg} \mathrm{b}$. wt. in conjunction with acarbose inhibited glucose level in streptozotocin-induced diabetic mice significantly. The Sonapatha seed extract increased the antioxidative capacity by elevating GSH, SOD, and HDL followed by reduced LOO and LDL levels in prediabetic mice [92]. The administration of $300 \mathrm{mg} / \mathrm{kg} \mathrm{b}$. wt. of aqueous and 
methanol extracts of Sonapatha leaves reduced the glucose, total cholesterol, triglyceride, protein, urea, and creatinine levels in alloxan-induced diabetic rats [93]. Administration of 200 and $400 \mathrm{mg} / \mathrm{kg} \mathrm{b}$. wt. of 50\% ethanol seed extract of Sonapatha for 21 days reduced serum glucose, triglyceride, and cholesterol levels in the glibenclamide-induced diabetic rats [94].

\subsection{Antiobesic Effect}

Obesity is one of the major health problems in humans and $13 \%$ of the adult world population is clinically obese. Obesity is associated with cardiovascular diseases, type II diabetes and certain cancers and Sonapatha has shown promise to reduce obesity preclinically. The 3T3-L1 adipocytes treated with hexanes, dichloromethane, ethyl acetate and methanol extracts of Sonapatha bark inhibited the lipid accumulation and lipase activity and the ethyl acetate extract was most effective [95]. Similarly, 3T3-L1 adipocytes exposed to 50, 100, 150 or $200 \mu \mathrm{g} / \mathrm{mL}$ of $95 \%$ Sonapatha ethanol fruit extract for 2 and 10 days suppressed the accumulation of lipids and lipase activity in 3T3-L1 adipocytes concentration-dependently. Sonapatha fruit extract also reduced lipids, lipid esters, nucleic acids, glycogen and carbohydrates in 3T3-L1 adipocytes [96]. The treatment of 3T3-L1 preadipocytes with 50,100, 150 or $200 \mu \mathrm{g} / \mathrm{mL}$ fruit extract of Sonapatha inhibited lipid accumulation and the greatest effect was observed for $200 \mu \mathrm{g} / \mathrm{mL}$. The study of mRNA expression showed that $200 \mu \mathrm{g} / \mathrm{mL}$ fruit extract suppressed the expression of fatty acid synthetase (FAS), sterol regulatory element-binding proteins 1c (SREBP-1c), proliferatoractivated receptor- $\gamma 2$ (PPAR $\gamma 2$ ), glucose transporter (GLUT4), and leptin in adipocytes indicating its potential as an antiobesity agent [97].

\subsection{Anticancer Effect}

The aqueous and methanol extracts of Sonapatha stem bark induced apoptosis in MDA-MB-435S (human breast carcinoma), Hep3B (human hepatic carcinoma), and PC-3 (human prostate cancer) cells [98]. The exposure of HeLa cells to 50, 100, 200, 250 and 500 petroleum ether, dichlromethane and methanol extracts of Sonapatha stem bark caused a concentration-dependent rise in the cytotoxic effect with an $\mathrm{IC}_{50}$ of $112.3 \pm 4.4,171.7 \pm 7.4$ and $315.7 \pm 6.5 \mu \mathrm{g} / \mathrm{mL}$ for petroleum ether, dichlromethane and methanol extracts, respectively. The petroleum ether extract was most cytotoxic and induced apoptosis indicated by membrane blebbing, nuclear fragmentation and apoptotic bodies and DNA fragmentation [62]. The petroleum and chloroform stem bark extract of Sonapatha has been reported to exert dose-dependent cytotoxicity in MDA-MB-231 and MCF-7 breast cancer cells by XTT assay and also induced apoptosis indicated by DNA fragmentation measured by ELISA [99]. The Sonapatha leaves extracted in methanol have shown the cytotoxic effect on HeLa cells with an $\mathrm{IC}_{50}$ of $3.87 \mu \mathrm{g} / \mathrm{mL}$, whereas it did not exert any cytotoxicity on normal Vero and MDCK cells. The methanol leaf extract of Sonapatha induced apoptosis, which was characterized by nuclear fragmentation, condensation, and apoptotic bodies. The apoptosis induction by methanol extract was further characterized by FITC-Annexin V and propidium iodide assay by flow cytometry analysis. The flow cytometric evaluation has revealed the collection of cells in the $G_{1} / S$ phase of the cell cycle by increasing p53 expression [100]. The cytotoxic effects of ethanol extract of wild Sonapatha and twigs cultured in vitro have triggered dose-dependent cytotoxicity in $\mathrm{SiHa}$ and HepG2 cells with $\mathrm{IC}_{50}$ of 440 and $480 \mu \mathrm{g} \mathrm{mL}^{-1}$, respectively for wild samples. However, the cytotoxicity was lower in the case of in vitro samples that exhibited the $\mathrm{IC}_{50}$ of 530 and $550 \mu \mathrm{g} \mathrm{mL}{ }^{-1}$ for SiHa and HepG2 cells, respectively [101]. The root bark of Sonapatha extracted in chloroform, ethyl acetate and n-butanol showed lethality in the brine shrimp assay and it was also cytotoxic to MCF-7 cells [102]. The leaf, bark, pod, and seeds of Sonapatha extracted in ethanol showed a concentration-dependent increase in cytotoxicity by sulforhodamine B and clonogenic assays with the $\mathrm{IC}_{50}$ of $161.2 \pm 8.63,286.73 \pm 33.01,149.03 \pm 8.81$, and $107.06 \pm 5.66 \mu \mathrm{g} / \mathrm{mL}$ for leaf, bark, pod, and seed extracts, respectively. The seed extract was most cytotoxic as indicated by colony-forming assay [103]. The leaves and fruit of Sonapatha extracted in 
ethanol were cytotoxic to MCF-7 cells in sulforhodamine B and clonogenic assays having an $\mathrm{IC}_{50}$ of $57.02 \pm 2.85 \mu \mathrm{g} / \mathrm{mL}$ and $131.3 \pm 19.2 \mu \mathrm{g} / \mathrm{mL}$, respectively. The leaf extract also inhibited cell migration, activated caspase 3 , and triggered apoptosis and suppressed the expression of MMP 9, ICAMP1, and Rac1 genes in MCF-7 cells. RhoA was significantly elevated by both leaf and fruit extracts in MCF-7 cells [104]. The methanol extract of Sonapatha leaves triggered cytotoxicity in a concentration-dependent manner with an $\mathrm{IC}_{50}$ of $6.25 \pm 1.06 \mu \mathrm{g} / \mathrm{mL}$. The cytotoxic effect of Sonapatha seems to be mediated by the downmodulation of HPV18 oncoproteins E6 and E7, followed by the activation of caspase- 8 and caspase- 3 and higher mRNA expressions of p53, pRb, Fas, and FasL in HeLa cells. The Sonapatha methanol leaf extract increased IL-12 and reduced the IL-6 production in HeLa cells [105].

\subsection{Wound Healing Effect}

The root bark of Sonapatha extracted in methanol has been reported to heal partial burn wounds in mice receiving the topical application of 1 and $2.5 \%$ extract containing ointment. This was evident by higher wound contraction and reduced wound healing time. The histological evaluation revealed a time-dependent progression in the formation of dermis and reepithelialization. The methanol extract of Sonapatha also increased collagen synthesis and $2.5 \%$ extract was superior to $1 \%$ [106]. Topical application of 5, 10, 20, and $30 \%$ ethanol stem bark extract of Sonapatha increased wound contraction and reduced the mean wound healing time in a dose-dependent manner of the full thickness excision wounds of mice. The $10 \%$ extract was most effective as it produced the highest wound contraction and reduced healing time maximally. The biochemical analysis of collagen and DNA syntheses showed a dose-dependent rise, accompanied by a decline in the LOO. The Western blot analysis showed that infliction of excision wound upregulated NF- $\mathrm{kB}$ and COX-2, whereas topical application of Sonapatha ethanol extract reduced their expression [14].

\subsection{Effect against COVID-19 Infection}

Coronavirus disease 2019 (COVID-19) is an infectious disease caused by coronavirus-2 (SARS-CoV-2). Covid-19 became a pandemic at the beginning of 2020 and since then several deaths have occurred worldwide. Covid-19 infection is characterized by a severe lifethreatening acute respiratory syndrome caused by hyperinflammatory response, vascular damage, microangiopathy, angiogenesis and widespread thrombosis. Currently, no specific treatment is available against COVID19 infection [107]. The COVID-19 entry into the primary host-cell is mediated by specific binding of coronavirus spike proteins (s) to the angiotensin-converting enzyme II (ACE2) receptors of human organs. Therefore, blocking of ACE2 can reduce COVID-19 entry into the cell. The molecular docking and the surface plasmon resonance studies have shown that oroxylin A present in Sonapatha can suppress the entry of the SARS-CoV-2-spiked pseudotyped virus into ACE2 cells, as it binds well to the ACE2 (blocking its availability for COVID-19) receptors as shown by surface plasmon resonance and cell membrane chromatography [108]. The $200 \mathrm{mg} / \mathrm{kg}$ baicalein another constituent of Sonapatha has been found to inhibit the replication of the COVID-19 virus and loss of body weight and reduce lung damage in hACE2 transgenic mice infected with SARS-CoV-2 and it also reduced SARS-CoV-2-induced injury in cultured Vero cells [109]. Baicalein inhibited the replication of SARS-CoV-2 in vitro with an $\mathrm{IC}_{50}$ of $10 \mu \mathrm{M}$ in Vero E6 cells by reducing oxygen consumption rate, oxidative phosphorylation and mitochondrial membrane potential [110]. Molecular docking studies against the SARS-CoV-2 virus replication enzyme main protease (Mpro) revealed that four (baicalein7-O-diglucoside, chrysin-7-O-glucuronide, oroxindin and scutellarein) of the eighteen constituents of Sonapatha had the potential to inhibit the activity of this enzyme and restrain COVID-19 infection [111]. 


\section{Mechanisms of Action}

The actual mechanism of action of Sonapatha in mitigating various disorders is not well understood. Sonapatha synthesizes several primary and secondary metabolites, and they individually or collectively may interact with multiple targets in the cells to bring the desired action against numerous ailments with less adverse effect than its constituents (Figure 2). Reactive oxygen species (ROS) generation is a fundamental mechanism, which is produced during oxidative phosphorylation as well as defense against foreign invaders into the body. However, excess ROS production is linked to inflammation and most human diseases. Therefore, one of the important mechanisms of action of Sonapatha seems to be its ability to scavenge different free radicals and increase various antioxidants such as GSH, glutathione-S-transferase (GST), GPx, catalase, and SOD and alleviate LOO, ALT, AST, ALP, LDH, GAA and GGT in normal tissues. Different extracts of Sonapatha have been reported to arrest cells in the $\mathrm{G}_{1} / \mathrm{S}$ phase of the cell cycle, suppress the expression of NF- $\mathrm{kB}$, COX-2, TNF $\alpha$, IL2, IL3, IL5, IL13, IL12, IL4, IL6, INF- $\gamma$, P38MAPK, MMP 9, ICAMP1, Rac1, FAS, SREBP-1c, PPAR $\gamma 2$, GLUT4, leptin, ACE2, and HPV18 oncoproteins E6 and E7. In contrast, Sonapatha upregulates the expression of p53, Bax, pRb, Fas, FasL, IL-12, RhoA, and caspases leading to various beneficial effects of Sonapatha in various study systems discussed above $[14,23,32-64,81-88,90-92,96,97,100,104,105,109,110]$.

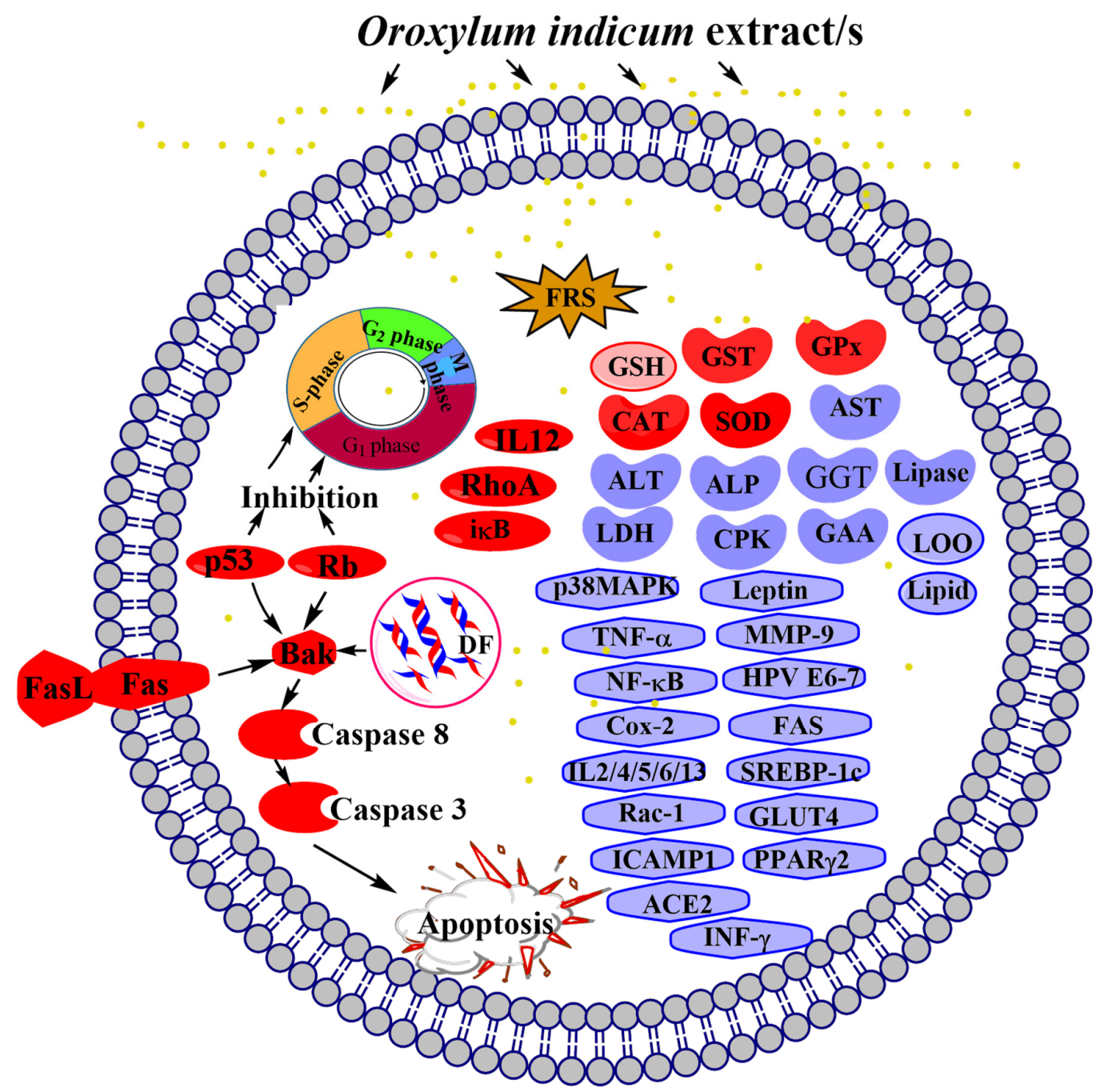

Figure 2. Mechanisms of action of Sonapatha (Oroxylum indicum). Red: activation/upregulation and blue: downregulation/reduction/deactivation. 
ACE2: angiotensin-converting enzyme II; ALP: alkaline phosphatase; ALT: alanine aminotransaminase; AST: aspartate transaminase; COX: cyclooxygenase; CPK: creatinine phosphokinase; DF: DNA fragmentation; FasL: Fas ligand; FAS: fatty acid synthetase; FRS: free radical scavenging; GAA: $\alpha$-glucosidase; GLUT4: glucose transporter; GPx: glutathione peroxidase; GSH: glutathione; GST: glutathione-s-transferase; HPV: human papilloma virus; IL: interleukin; IkB: nuclear factor of kappa light polypeptide gene enhancer in B-cells inhibitor; INF- $\gamma$ : interferon- $\gamma$; LDH: lactate dehydrogenase; LOO: lipid peroxidation; MAPK: microtubule associated protein kinase; MMP: matrix metalloproteinase; NF-кB: nuclear factor kappa B; Rac: Ras-related C3 botulinum toxin substrate; Rb: retinoblastoma protein; Rho: Ras homolog family member; SOD: superoxide dismutase; TNF: tumor necrosis factor; sterol regulatory element-binding proteins 1c (SREBP-1c); PPAR $\gamma 2$ : proliferator-activated receptor- $\gamma 2$.

\section{Conclusions}

Sonapatha is used in traditional and Ayurvedic systems of medicine to treat numerous human disorders. The scientific evaluation of Sonapatha has established its analgesic, anti-inflammatory, anthelmintic, antimicrobial, antidiabetic, anti-obesity, hepatoprotective, cardioprotective, gastroprotective, anticancer, and wound healing activities in various preclinical models in vitro and in vivo. The therapeutic potential of Sonapatha seems to be due to its ability to scavenge free radicals, elevate GSH, GST, GPx, catalase, and SOD levels, and reduce LOO, as most human ailments are triggered by increased oxidative stress. In addition, Sonapatha reduces lipid accumulation and lipase activity. At the molecular level, Sonapatha inhibits the activation of NF-kB, COX-2, TNF $\alpha$, IL2, IL3, IL5, IL13, IL12, IL4, IL6, INF- $\gamma$, P38 MAPK, MMP 9, ICAMP1, Rac1, HPV18 oncoproteins E6 and E7, FAS, SREBP-1c, PPAR $\gamma$ c2, GLUT4, and leptin. Sonapatha upregulates the activation of p53, pRb, Fas, FasL, IL-12, RhoA, and caspases 8/3, which may be related to its cytotoxic, anti-inflammatory, antidiabetic, antiobesity, hepatoprotective, gastroprotective, cardioprotective, and wound healing activities. The experimental and molecular docking studies have revealed that active constituents of Sonapatha including oroxylin A, baicalein, and chrysin have the potential to act against the COVID-19 infection by blocking the ACE2 receptors and attenuating the activity of enzyme main protease, which aid in the replication of SARS-CoV-2 in humans.

Funding: This research received no external funding.

Institutional Review Board Statement: Not applicable.

Acknowledgments: I wish to acknowledge the constant support, encouragement, and patience of my wife Mangla Jagetia during the writing of this manuscript.

Conflicts of Interest: The author does not have any conflict-of-interest statement to declare.

\footnotetext{
Abbreviations

ACE2: angiotensin-converting enzyme II; ALP: alkaline phosphatase; ALT: alanine aminotransaminase; AST: aspartate transaminase; COX: cyclooxygenase; CPK: creatinine phosphokinase; FasL: Fas ligand; FAS: fatty acid synthetase; FRS: free radical scavenging; GAA: $\alpha$-glucosidase; GLUT4: glucose transporter; GPx: glutathione peroxidase; GSH: glutathione; GST: glutathione-s-transferase; HDL: high-density lipoprotein; HPV: human papilloma virus; IкB: nuclear factor of kappa light polypeptide gene enhancer in B-cells inhibitor; LDH: lactate dehydrogenase; LOO: lipid peroxidation; LDL: low-density lipoprotein; HDL: high-density lipoprotein; MAPK: microtubule associated protein kinase; MMP: matrix metalloproteinase; Mo: molybdenum; INF- $\gamma$ : interferon- $\gamma$; IL: interleukin; NF-KB: nuclear factor kappa B; PPARc2: proliferator-activated receptor $\gamma$ 2; Rac: Ras-related C3 botulinum toxin substrate; $\mathrm{Rb}$ : retinoblastoma protein; Rho: Ras homolog family member; SOD: superoxide dismutase; SREBP-1c: sterol regulatory element-binding proteins 1c; TNF: tumor necrosis factor.
} 


\section{References}

1. Kirtikar, K.; Basu, B. Indian Medicinal Plants; Oriental Enterprises: Deharadun, India, 2001; Volume 4.

2. Dalal, N.V.; Rai, V.R. In vitro propagation of Oroxylum indicum Vent. a medicinally important forest tree. J. For. Res. 2004, 9, 61-65. [CrossRef]

3. Paranjpe, P. Indian Medicinal Plants; Chaukhamba Sanskrit Pratishthan: Delhi, India, 2005.

4. Theobald, W. Bignoniaceae. In A Revised Handbook to the Flora of Ceylon; Dassanayake, M.D., Fosberg, F.R., Eds.; Amerind Publishing Co. Pvt. Ltd.: New Delhi, India, 1981.

5. Chauhan, N. Medicinal and Aromatic Plants of Himachal Pradesh; Indus Publishing: New Delhi, India, 1999.

6. Rasadah, M.A.; Houghton, P.J.; Raman, A.; Hoult, J.R.S. Antimicrobial and antiinflammatory activities of extracts and constituents of Oroxylum indicum (L.) Vent. Phytomedicine 1998, 5, 375-381. [CrossRef]

7. Rasadah, M.A. Oroxylum indicum (L.) Kurz. In Plant Resources of South-East Asia No. 12 (2): Medicinal and Poisonous Plants 2; van Valkenberg, J.L.C.H., Bunyapraphatsara, N., Eds.; Backhuys Publisher: Leiden, The Netherlands, 2001 ; ISBN 9057820994.

8. Dev, L.R.; Anurag, M.; Rajiv, G. Oroxylum indicum: A review. Pharmacogn. J. 2010, 2, 304-310. [CrossRef]

9. Jayaram, K.; Prasad, M. Genetic diversity in Oroxylum indicum (L.) Vent. (Bignoniaceae), a vulnerable medicinal plant by random amplified polymorphic DNA marker. Afr. J. Biotechnol. 2008, 7, 254-262.

10. Singh, A.K. Morphological expressions in seedlings of Oroxylum indicum (L.) Vent-A well known medicinal tree of tropics and subtropics. Mod. Phytomorphol. 2015, 8, 41-48.

11. Warrier, P.; Nambiar, V.; Ramankutty, C. Indian Medicinal Plants-A Compendium of 500 Species; Orient Longman Ltd.: Chennai, India, 1995.

12. Nakahara, K.; Trakoontivakorn, G.; Alzoreky, N.S.; Ono, H.; Onishi-Kameyama, M.; Yoshida, M. Antimutagenicity of some edible Thai plants, and a bioactive carbazole alkaloid, mahanine, isolated from Micromelum minutum. J. Agric. Food Chem. 2002, 50, 4796-4802. [CrossRef]

13. Lalrinzuali, K.; Vabeiryureilai, M.; Jagetia, G.C. Phytochemical and TLC profiling of Oroxylum indicum and Milletia pachycarpa. J. Plant Biochem. Physiol. 2015, 3. [CrossRef]

14. Lalrinzuali, K.; Vabeiryureilai, M.; Jagetia, G.C. Topical application of stem bark ethanol extract of Sonapatha, Oroxylum indicum (L.) Kurz accelerates healing of deep dermal excision wound in Swiss albino mice. J. Ethnopharmacol. 2018, 227, 290-299. [CrossRef]

15. Dinda, B.; Silsarma, I.; Dinda, M.; Rudrapaul, P. Oroxylum indicum (L.) Kurz, an important Asian traditional medicine: From traditional uses to scientific data for its commercial exploitation. J. Ethnopharmacol. 2015, 161, 255-278. [CrossRef]

16. Balkrishna, A. Ayurved Jadi-Booti Rahasya; Divyaprakasan, Divya Yog Mandir Trust: Haridwar, India, 2005; ISBN 81-89235-44-8.

17. Singh, H.B.; Prasad, P.; Rai, L.K. Folk Medicinal Plants in the Sikkim Himalayas of India. Asian Folk Studs 2002, 61, 295-310. [CrossRef]

18. Bhattacharje, S. Use of flavours and fragrances. In Handbook of Aromatic Plants, 2nd ed.; Bhattacharje, S.K., Ed.; Pointer Publishers: Jaipur, India, 2005; ISBN 8171324071.

19. Khare, C. Indian Herbal Remedies: Rational Western Therapy, Ayurvedic, and Other Traditional Usage, Botany, 4th ed.; Springer: Berlin/Heidelberg, Germany; New York, NY, USA, 2004; ISBN 3-540-01026-2.

20. Jamir, N.S.; Takatemjen; Limasemba. Traditional knowledge of Lotha-Naga tribes in Wokha district, Nagaland. Indian J. Tradit. Knowl. 2010, 9, 45-48.

21. Gaur, R.D.; Sharma, J. Indigenous knowledge on the utilization of medicinal plant diversity in the Siwalik region of Garhwal Himalaya, Uttarakhand. J. For. Environ. Sci. 2011, 27, 23-31.

22. Rout, S.D.; Panda, T.; Mishra, N. Ethno-medicinal plants used to cure different diseases by tribals of Mayurbhanj district of north Orissa. Stud. Ethno-Med. 2009, 3, 27-32. [CrossRef]

23. Das, S.; Duttachoudhury, M.; Mandal, S.C.; Talukdar, A. Traditional knowledge of ethnomedicinal hepatoprotective plants used by certain ethnic communities of Tripura state. Indian J. Fundam. Appl. Life Sci. 2012, 2, 84-97.

24. Nadkarni, K. Indian Materia Medica, 3rd ed.; Popular Prakashan: Bombay, India, 1982.

25. Chopra, R.N.; Nayar, S.L.; Chopra, I.C. Glossary of Indian Medicinal Plants; National Institute of Science Communication and Information Resources: New Delhi, India, 2002.

26. Drury, C.H. Ayurvedic Useful Plants of India; Asiatic Publishing House: Delhi, India, 2010; ISBN 819080913X.

27. Patil, G.; Mali, P.; Bhadane, V. Folk remedies used against respiratory disorders in Jalgaon district, Maharashtra. Nat. Prod. Radiance 2008, 7, 354-358.

28. Panghal, M.; Arya, V.; Yadav, S.; Kumar, S.; Yadav, J.P. Indigenous knowledge of medicinal plants used by Saperas community of Khetawas, Jhajjar District, Haryana, India. J. Ethnobiol. Ethnomed. 2010, 6. [CrossRef]

29. National Register of Medicinal Plants; IUCN Nepal: Kathmandu, Nepal, 2000; ISBN 92-9144-048-5.

30. Fazlin, A.; Ahmad, Z.; Lim, H.H. Compendium of Medicinal Plants Used in Malaysia; Herbal Medicine Research Centre, Institute for Medical Research, Aktif Bestari Sdn Bhd: Kuala Lumpur, Malaysia, 2002; Volume 2.

31. DeFilipps, R.A.; Krupnick, G.A. The medicinal plants of Myanmar. PhytoKeys 2018, 102, 1-341. [CrossRef] [PubMed]

32. Kalaivani, T.; Mathew, L. Phytochemistry and free radical scavenging activities of Oroxylum indicum. Environ. We Int. J. Sci. Technol. 2009, 4, 45-52. 
33. Radhika, L.G.; Meena, C.V.; Peter, S.; Rajesh, K.S.; Rosamma, M.P. Phytochemical and antimicrobial study of Oroxylum indicum. Anc. Sci. Life 2011, 30, 114-120.

34. Samatha, T.; Srinivas, P.; Shyamsundarachary, R.; Rajinikanth, M.; Rama Swamy, N. Phytochemical analysis of seeds, stem bark and root of an endangered medicinal forest tree Oroxylum indicum (L.) Kurz. Int. J. Pharma Bio Sci. 2012, 3, B1063-B1075.

35. Das, B.K.; Al-Amin, M.M.; Russel, S.M.; Kabir, S.; Bhattacherjee, R.; Hannan, J.M.A. Phytochemical screening and evaluation of analgesic activity of Oroxylum indicum. Indian J. Pharm. Sci. 2014, 76, 571-575. [PubMed]

36. SatyaEswari, J.; Dhagat, S.; Naik, S.; Dibya, S. Oroxylum indicum leaf extracts for screening of antimicrobial properties and phytochemicals. Pharm. Bioprocess. 2018, 6, 7-14.

37. Subramanian, S.; Nair, A. Flavanoids of the leaves of Oroxylum indicum and Pajanelia longifolia. Phytochemistry 1972, 11, 439-440. [CrossRef]

38. Zaghloul, S.; Azzam, S.; Eid, H.; Hassan, H.; Sleem, A. Chemical and biological investigation of essential oil of Oroxylum indicum L. leaves cultivated in Egypt. Int. J. Pharmacogn. Phytochem. Res. 2015, 7, 570-575.

39. Luitel, H.; Rajbhandari, M.; Kalauni, S.; Awale, S.; Masuda, K.; Gewali, M. Chemical constituents from Oroxylum indicum (L.) Kurz of Nepalese Origin. Sci. World 2010, 8, 66-68. [CrossRef]

40. Babu, T.; Manjulatha, K.; Kumar, G.; Hymavathi, A.; Tiwari, A.; Purohit, M.; Rao, J.; Babu, K. Gastroprotective flavonoid constituents from Oroxylum indicum Vent. Bioorg. Med. Chem. Lett. 2010, 20, 117-120. [CrossRef]

41. Nguyen, M.; Nguyen, N.; Nguyen, X.; Huynh, T.; Min, B. Screening of $\alpha$-glucosidase inhibitory activity of Vietnamese medicinal plants: Isolation of active principles from Oroxylum indicum. Nat. Prod. Sci. 2012, 18, 47-51.

42. Islam, K.; Eti, Z.; Chowdhury, J.A. Phytochemical and antimicrobial analysis on the extract of Oroxylum indicum Linn. stem-bark. Iran. J. Pharmacol. Ther. 2010, 9, 25-28.

43. Fan, Q.F.; Hu, Z.Y.; Na, Z.; Tang, H.S.; Zuo, G.Y.; Song, Q.S. One new flavonoid from Oroxylum indicum. Nat. Prod. Res. 2015, 29, 1828-1832. [CrossRef]

44. Zaveri, M.; Khandhar, A.; Jain, S. Quantification of baicalein, chrysin, biochanin-A and ellagic acid in root bark of Oroxylum indicum by RP-HPLC with UV detection. Eurasian J. Anal. Chem. 2008, 3, 245-257.

45. Uddin, K.; Sayeed, A.; Islam, A.; Rahman, A.; Ali, A.; Khan, G.R.M.A.; Sadik, M. Purification, characterization and cytotoxic activity of two flavonoids from Oroxylum indicum Vent. (Bignoniaceae). Asian J. Plant Sci. 2003, 2, 515-518. [CrossRef]

46. Yadav, A.K.; Manika, N.; Bagchi, D.; Gupta, M. Simultaneous determination of flavonoids in Oroxylum indicum by RP-HPLC. Med. Chem. Res. 2013, 22, 2222-2227. [CrossRef]

47. Mehta, C.; Mehta, T. Tetuin, a glucoside from the seeds of Oroxylum indicum Vent. Curr. Sci. 1953, $22,114$.

48. Nair, A.; Joshi, B. Oroxindin-A new flavone glucuronide from Oroxylum indicum Vent. Proc. Indian Acad. Sci. 1979, 88, 323-327.

49. Chen, L.J.; Games, D.E.; Jones, J. Isolation and identification of four flavonoid constituents from the seeds of Oroxylum indicum by high-speed counter-current chromatography. J. Chromatogr. A 2003, 988, 95-105. [CrossRef]

50. Yan, R.Y.; Cao, Y.Y.; Chen, C.Y.; Dai, H.Q.; Yu, S.X.; Wei, J.L.; Li, H.; Yang, B. Antioxidant flavonoids from the seed of Oroxylum indicum. Fitoterapia 2011, 82, 841-848. [CrossRef]

51. Wei, X.N.; Lin, B.; Xie, G.Y.; Li, J.W.; Qin, M.J. Chemical constituents of seeds of Oroxylum indicum. Zhongguo Zhongyao Zazhi 2013, 38, 204-207. [CrossRef]

52. Krüger, A.; Ganzera, M. Oroxylum indicum seeds-analysis of flavonoids by micellar electrokinetic chromatography. Chromatography 2013, 1, 1-8. [CrossRef]

53. Li, G.; Wang, G.; Tong, Y.; Zhu, J.; Yun, T.; Ye, X.; Li, F.; Yuan, S.; Liu, Q. Concise synthesis and antidiabetic activity of natural flavonoid glycosides, oroxins C and D, isolated from the seeds of Oroxylum indium. J. Chem. Res. 2021, 45, 68-75. [CrossRef]

54. Rojsanga, P.; Bunsupa, S.; Sithisarn, P. Flavones contents in extracts from Oroxylum indicum seeds and plant tissue cultures. Molecules 2020, 25, 1545. [CrossRef]

55. Rojsanga, P.; Bunsupa, S.; Brantner, A.H.; Sithisarn, P. Comparative phytochemical profiling and in vitro antioxidant activity of extracts from raw materials, tissue-cultured plants, and callus of Oroxylum indicum (L.) Vent. Evid. Based Complement. Altern. Med. 2017, 2017, 6853212. [CrossRef] [PubMed]

56. Jiwajinda, S.; Santisopasri, V.; Murakami, A.; Kim, O.; Kim, H.; Ohigashi, H. Suppressive effects of edible Thai plants on superoxide and nitric oxide generation. Asian Pac. J Cancer Prev. 2002, 3, 215-223. [PubMed]

57. Chumkaew, P.; Srisawat, T. A new flavone from Oroxylum indicum and its antibacterial activity. Chem. Nat. Compd. 2021, 57, 274-276. [CrossRef]

58. Mishra, S.L.; Sinhamahapatra, P.K.; Nayak, A.; Das, R.; Sannigrahi, S. In vitro antioxidant potential of different parts of Oroxylum indicum: A comparative study. Indian J. Pharm. Sci. 2010, 72, 267-269. [CrossRef]

59. Tenpe, C.; Upaganlawar, A.; Burle, S.; Yeole, P. In vitro antioxidant and preliminary hepatoprotective activity of Oroxylum indicum Vent leaf extracts. Pharmacologyonline 2009, 1, 35-43.

60. Gupta, R.C.; Sharma, V.; Sharma, N.; Kumar, N.; Singh, B. In vitro antioxidant activity from leaves of Oroxylum indicum (L.) Vent.-A North Indian highly threatened and vulnerable medicinal plant. J. Pharm. Res. 2008, 1, 65-72.

61. Kumar, V.; Chaurasia, A.K.; Naglot, A.; Gopalakrishnan, R.; Gogoi, B.J.; Singh, L.; Srivastava, R.B.; Deka, D.C. Antioxidant and antimicrobial activities of stem bark extracts of Oroxylum indicum Vent. (Bignoniaceae)—A medicinal plant of northeastern India. South Asian J. Exp. Biol. 2011, 1, 152-157. 
62. Moirangthem, D.S.; Talukdar, N.C.; Bora, U.; Kasoju, N.; Das, R.K. Differential effects of Oroxylum indicum bark extracts: Antioxidant, antimicrobial, cytotoxic and apoptotic study. Cytotechnology 2013, 65, 83-95. [CrossRef]

63. Lalrinzuali, K.; Vabeiryureilai, M.; Jagetia, G.C.; Lalawmpuii, P.C. Free radical scavenging and antioxidant potential of different extracts of Oroxylum indicum in vitro. Adv. Biomed. Pharma 2015, 2, 120-130. [CrossRef]

64. Sithisarn, P.; Nantateerapong, P.; Rojsanga, P.; Sithisarn, P. Screening for antibacterial and antioxidant activities and phytochemical analysis of Oroxylum indicum fruit extracts. Molecules 2016, 21, 446. [CrossRef]

65. Upaganlawar, A.; CR, T.; Yeole, P. Antiinflammatory activity of aqueous extract of Oroxylum indicum Vent. leaves extractpreliminary study. Pharmacol. Online 2009, 1, 22-26.

66. Doshi, K.; Ilanchezhian, R.; Acharya, R.; Patel, B.R.; Ravishankar, B. Anti-inflammatory activity of root bark and stem bark of Shyonaka. J. Ayurveda Integr. Med. 2012, 3, 194-197. [CrossRef]

67. Joshi, S.V.; Vyas, B.A.; Shah, P.D.; Shah, D.R.; Shah, S.A.; Gandhi, T.R. Protective effect of aqueous extract of Oroxylum indicum Linn. (root bark) against DNBS-induced colitis in rats. Indian J. Pharmacol. 2011, 43, 656-661. [CrossRef]

68. Asaduzzaman, M.; Nasrin, N.; Muhit, A.; Raihan, S.; Apu, A.; Akbar, A. Antidiarrheal, analgesic and cytotoxic activities of crude extract of Oroxylum indicum (L.) stem bark. J. Pharm. Res. 2011, 4, 4296-4298.

69. Hu, T.; Liu, S.; Zhao, L.; Qin, K. Preparation of Oroxylum indicum extracts and their anti-bacterial and anti-inflammatory activities. China Anim. Husb. Vet. Med. 2010, 37, 225-228.

70. Lalrinzuali, K.; Vabeiryureilai, M.; Jagetia, G.C. Investigation of the anti-inflammatory and analgesic activities of ethanol extract of stem bark of sonapatha Oroxylum indicum in vivo. Int. J. Inflam. 2016, 2016, 8247014. [CrossRef]

71. Laloo, D.; Gogoi, B.; Lyngdoh, W.; Zaman, K.; Sharma, H. Antioxidant, analgesic and anti-inflammatory activities of bark of Oroxylum indicum Vent: An endemic medicinal plant of Northeast India. Asian J. Chem. 2016, 28, 2272-2276. [CrossRef]

72. Begum, M.M.; Islam, A.; Begum, R.; Uddin, M.S.; Rahman, M.S.; Alam, S.; Akter, W.; Das, M.; Rahman, M.S.; Imon, A.H.M.R. Ethnopharmacological inspections of organic extract of Oroxylum indicum in rat models: A promising natural gift. Evid. Based. Complement. Alternat. Med. 2019, 2019, 1562038. [CrossRef]

73. Bergeron, C.; Hamid, Q. Relationship between asthma and rhinitis: Epidemiologic, pathophysiologic, and therapeutic aspects. Allergy Asthma Clin. Immunol. 2005, 1, 81-87. [CrossRef]

74. Lee, A.Y.; Kang, S.; Park, S.J.; Huang, J.; Im, D.S. Anti-allergic effect of oroxylin a from Oroxylum indicum using in vivo and in vitro experiments. Biomol. Ther. 2016, 24, 283-290. [CrossRef]

75. Rasadah, M.A.; Houghton, P.J.; Hoo, T.S. Antifungal activity of some Bignoniaceae found in Malaysia. Phyther. Res. 1998, 12, 331-334. [CrossRef]

76. Samatha, T.; Sampath, A.; Sujatha, K.; Rama Swamy, N. Antibacterial activity of stem bark extracts of Oroxylum indicum an endangered ethnomedicinal forest tree. IOSR J. Pharm. 2011, 7, 24-28.

77. Das, S.; Choudhury, M.D. Antimicrobial activity of stem bark extracts from the plant Oroxylum indicum Vent. Assam Univ. J. Sci. Technol. 2010, 5, 95-99.

78. Deori, K.; Yadav, A.K. Anthelmintic effects of Oroxylum indicum stem bark extract on juvenile and adult stages of Hymenolepis diminuta (Cestoda), an in vitro and in vivo study. Parasitol. Res. 2016, 115, 1275-1285. [CrossRef]

79. Islam, M.; Rahman, M.M.; Hasan, M.; Rahaman, M.; Khan, M.R.H.; Al-Faysal, A. Evaluation of anthelmintic activity of crude extracts and different fractions of stem bark and fruits of Oroxylum indicum. World J. Pharm. Res. 2016, 5, 287-294. [CrossRef]

80. Tripathy, B.; Panda, S.; Sahoo, S.; Mishra, S.; Nayak, L. Phytochemical analysis and hepatoprotective effect of stem bark of Oroxylum indicum (L) Vent. on carbon tetrachloride induced hepatotoxicity in rat. Int. J. Pharm. Biol. Arch. 2011, 2, $1714-1717$.

81. Sastry, A.; Sastry, V.; Mallikarjun, P.; Srinivas, K. Chemical and pharmacological evaluation of aqueous extract of root bark of "Oroxylum indicum" Vent. Int. J. Pharm. Technol. 2011, 3, 1796-1806.

82. Mishra, S.; Sahoo, S. In vitro and in vivo antihepatotoxic activity of Oroxylum indicum against carbon-tetrachloride induced hepatic damage. Int. J. Pharm. Sci. Res. 2013, 4, 3202-3207. [CrossRef]

83. Bharali, M.K.; Konya, H.; Bahadur, C.L. Protective effect of Oroxylum indicum on acetaminophen induced liver injury in rat. Int. Curr. Pharm. J. 2014, 3, 223-227. [CrossRef]

84. More, A.; Shah, T.; Parab, P.; Apte, K. Oroxylum indicum (Linn.) whole stem extract regulates expression of TNF $\alpha$, IL6, NFkB, P38 MAPK and oxidative status in antitubercular therapy induced hepatotoxicity in Wistar rats. Matters 2017, 3, e201704000014. [CrossRef]

85. Mohapatra, S.S.; Roy, R.; Mohan, P.; Upadhyaya, T.; Sarma, J. Phytochemical analysis and hepatoprotective effect of hydroethanolic extract of stem bark of Oroxylum indicum. Int. J. Curr. Microbiol. Appl. Sci. 2018, 7, 1000-1006. [CrossRef]

86. Sun, W.; Liu, P.; Yang, B.; Wang, M.; Wang, T.; Sun, W.; Wang, X.; Zheng, W.; Song, X.; Li, J. A network pharmacology approach: Inhibition of the NF- $\mathrm{kB}$ signaling pathway contributes to the NASH preventative effect of an Oroxylum indicum seed extract in oleic acid-stimulated HepG2 cells and high-fat diet-fed rats. Phytomedicine 2021. [CrossRef]

87. Zaveri, M.; Jain, S. Gastroprotective effects of root bark of Oroxylum indicum, Vent. J. Nat. Remedies 2007, 7, 269-277. [CrossRef]

88. Menon, S.; Lawrence, L.; Sivaram, V.P.; Padikkala, J. Oroxylum indicum root bark extract prevents doxorubicin-induced cardiac damage by restoring redox balance. J. Ayurveda Integr. Med. 2019, 10, 159-165. [CrossRef] [PubMed]

89. Tamboli, A.; Karpe, S.; Shaikh, S.; Manikrao, A. Hypoglycemic activity of extracts of Oroxylum indicum (L.) vent roots in animal models. Pharmacologyonline 2011, 2, 890-899. 
90. Singh, J.; Kakkar, P. Modulation of liver function, antioxidant responses, insulin resistance and glucose transport by Oroxylum indicum stem bark in STZ induced diabetic rats. Food Chem. Toxicol. 2013, 62, 722-731. [CrossRef] [PubMed]

91. Zhang, B.W.; Sang, Y.B.; Sun, W.; Yu, H.S.; Ma, B.P.; Xiu, Z.L.; Dong, Y.S. Combination of flavonoids from Oroxylum indicum seed extracts and acarbose improves the inhibition of postprandial blood glucose: In vivo and in vitro study. Biomed. Pharmacother. 2017, 91, 890-898. [CrossRef]

92. Sun, W.; Sang, Y.; Zhang, B.; Yu, X.; Xu, Q.; Xiu, Z.; Dong, Y. Synergistic effects of acarbose and an Oroxylum indicum seed extract in streptozotocin and high-fat-diet induced prediabetic mice. Biomed. Pharmacother. 2017, 87, 160-170. [CrossRef] [PubMed]

93. Kaldate, P.; Tenpe, C.; Rapid, P.Y. Antidiabetic activity of leaves of Oroxylum indicum in alloxan-induced diabetic rats. Inven. Rapid Ethnopharmacol. 2011, 1, 468.

94. Mishra, S.B.; Simon, M.; Mukerjee, A.; Rani, S.; Parashar, T. Phytochemical investigation and antidiabetic activity of Oroxylum indicum Vent. seed. SSRN Electron. J. 2018. [CrossRef]

95. Mangal, P.; Khare, P.; Jagtap, S.; Bishnoi, M.; Kondepudi, K.K.; Bhutani, K.K. Screening of six Ayurvedic medicinal plants for anti-obesity potential: An investigation on bioactive constituents from Oroxylum indicum (L.) Kurz bark. J. Ethnopharmacol. 2017, 197, 138-146. [CrossRef] [PubMed]

96. Hengpratom, T.; Lowe, G.M.; Thumanu, K.; Suknasang, S.; Tiamyom, K.; Eumkeb, G. Oroxylum indicum (L.) Kurz extract inhibits adipogenesis and lipase activity in vitro. BMC Complement. Altern. Med. 2018, 18, 177. [CrossRef] [PubMed]

97. Hengpratom, T.; Ngernsoungnern, A.; Ngernsoungnern, P.; Lowe, G.M.; Eumkeb, G. Antiadipogenesis of Oroxylum indicum (L.) Kurz extract via PPAR $\gamma 2$ in 3T3-L1 adipocytes. Evid. Based Complement. Altern. Med. 2020, 2020, 6720205. [CrossRef] [PubMed]

98. Rajkumar, V.; Guha, G.; Kumar, R. Induction of apoptosis in MDA-MB-435S, Hep3B and PC-3 cell lines by extracts of Oroxylum indicum. J. Pharm. Res. 2011, 4, 2054-2056.

99. Kumar, D.R.N.; George, V.C.; Suresh, P.K.; Kumar, R.A. Cytotoxicity, apoptosis induction and anti-metastatic potential of Oroxylum indicum in human breast cancer cells. Asian Pac. J. Cancer Prev. 2012, 13, 2729-2734. [CrossRef]

100. Zazali, K.E.; Abdullah, H.; Jamil, N.I.N. Methanol extract of Oroxylum indicum leaves induces $\mathrm{G}_{1} / \mathrm{S}$ cell cycle arrest in HeLa cells via p53-mediated pathway. Int. J. Med. Plant Res. 2013, 2, 225-237.

101. Kumari, N.; Kumar, R.; Sinha, K.; Kumar, S. Anticancerous potentiality of in vivo grown twigs and in vitro generated plantlets of endangered Oroxylum indicum (L.) Vent. IOSR J. Biotechnol. Biochem. 2018, 4, 21-27. [CrossRef]

102. Dhru, B.; Bhatt, D.; Jethva, K.; Zaveri, M. In vitro cytotoxicity studies of the anti-cancer potential of fractions of root bark of Oroxylum indicum in human breast carcinoma cells. Int. J. Pharm. Sci. Rev. Res. 2016, 38, 18-21.

103. Buranrat, B.; Noiwetch, S.; Suksar, T.; Ta-ut, A.; Boontha, S. Cytotoxic and antimigration effects of different parts of Oroxylum indicum extract on human breast cancer MCF-7 cells. Sci. Technol. Asia 2018, 23, 42-52. [CrossRef]

104. Buranrat, B.; Noiwetch, S.; Suksar, T.; Ta-ut, A. Inhibition of cell proliferation and migration by Oroxylum indicum extracts on breast cancer cells via Rac1 modulation. J. Pharm. Anal. 2020, 10, 187-193. [CrossRef]

105. Wahab, N.; Din, N.; Lim, Y.; Jamil, N.; Mat, N. Proapoptotic activities of Oroxylum indicum leave extract in HeLa cells. Asian Pac. J. Trop. Biomed. 2019, 9, 339-345.

106. Singh, H.; Singh, V.; Kumar, D.; Chaudhary, A. Wound healing and antimicrobial potential of Oroxylum indicum Vent. in albino mice. Nat. Prod. J. 2011, 1, 128-134. [CrossRef]

107. Stasi, C.; Fallani, S.; Voller, F.; Silvestri, C. Treatment for COVID-19: An overview. Eur. J. Pharmacol. 2020, 889, 173644. [CrossRef] [PubMed]

108. Gao, J.; Ding, Y.; Wang, Y.; Liang, P.; Zhang, L.; Liu, R. Oroxylin A is a severe acute respiratory syndrome coronavirus 2spiked pseudotyped virus blocker obtained from Radix scutellariae using angiotensin-converting enzyme II/cell membrane chromatography. Phyther. Res. 2021, 10, 1002. [CrossRef]

109. Song, J.; Zhang, L.; Xu, Y.; Yang, D.; Yang, S.; Zhang, W.; Wang, J.; Tian, S.; Yang, S.; Yuan, T.; et al. The comprehensive study on the therapeutic effects of baicalein for the treatment of COVID-19 in vivo and in vitro. Biochem. Pharmacol. 2021, 183, 114302. [CrossRef] [PubMed]

110. Huang, S.; Liu, Y.; Zhang, Y.; Zhang, R.; Zhu, C.J.; Fan, L.; Pei, G.; Zhang, B.; Shi, Y. Baicalein inhibits SARS-CoV-2/VSV replication with interfering mitochondrial oxidative phosphorylation in a MPTP dependent manner. Signal Transduct. Target. Ther. 2020, 5, 266. [CrossRef] [PubMed]

111. Shah, S.; Chaple, D.; Arora, S.; Yende, S.; Moharir, K.; Lohiya, G. Exploring the active constituents of Oroxylum indicum in intervention of novel coronavirus (COVID-19) based on molecular docking method. Netw. Model. Anal. Health Informat. Bioinform. 2021, 10, 8. [CrossRef] [PubMed] 